\title{
Cushion bogs are stronger carbon dioxide net sinks than moss-dominated bogs as revealed by eddy covariance measurements on Tierra del Fuego, Argentina
}

\author{
David Holl $^{1}$, Verónica Pancotto ${ }^{2,3}$, Adrian Heger ${ }^{1}$, Sergio Jose Camargo ${ }^{3,4}$, and Lars Kutzbach ${ }^{1}$ \\ ${ }^{1}$ Institute of Soil Science, Center for Earth System Research and Sustainability (CEN), \\ Universität Hamburg, Hamburg, Germany \\ ${ }^{2}$ Centro Austral de Investigaciones Científicas (CADIC-CONICET), Ushuaia, Argentina \\ ${ }^{3}$ Universidad de Tierra del Fuego (ICPA-UNTDF), Ushuaia, Argentina \\ ${ }^{4}$ Dirección de Cambio Climático (DCC), Secretaría de Estado de Ambiente, \\ Desarrollo Sostenible y Cambio Climático (SADSyCC), Ushuaia, Argentina
}

Correspondence: David Holl (david.holl@uni-hamburg.de)

Received: 24 April 2019 - Discussion started: 8 May 2019

Revised: 2 August 2019 - Accepted: 5 August 2019 - Published: 12 September 2019

\begin{abstract}
The near-pristine bog ecosystems of Tierra del Fuego in southernmost Patagonia have so far not been studied in terms of their current carbon dioxide $\left(\mathrm{CO}_{2}\right)$ sink strength. $\mathrm{CO}_{2}$ flux data from Southern Hemisphere peatlands are scarce in general. In this study, we present $\mathrm{CO}_{2}$ net ecosystem exchange (NEE) fluxes from two Fuegian bog ecosystems with contrasting vegetation communities. One site is located in a glaciogenic valley and developed as a peat moss-dominated raised bog, and the other site is a vascular plant-dominated cushion bog located at the coast of the Beagle Channel. We measured NEE fluxes with two identical eddy covariance (EC) setups at both sites for more than 2 years. With the EC method, we were able to observe NEE fluxes on an ecosystem level and at high temporal resolution. Using a mechanistic modeling approach, we estimated daily NEE models to gap fill and partition the half-hourly net $\mathrm{CO}_{2}$ fluxes into components related to photosynthetic uptake (gross primary production, GPP) and to total ecosystem respiration (TER). We found a larger relative variability of annual NEE sums between both years at the moss-dominated site. A warm and dry first year led to comparably high TER sums. Photosynthesis was also promoted by warmer conditions but less strongly than TER with respect to absolute and relative GPP changes. The annual NEE carbon (C) uptake was more than 3 times smaller in the warm year. Close to the sea at the cushion bog site, the mean temperature difference between both observed years was less pronounced, and TER
\end{abstract}

stayed on similar levels. A higher amount of available radiation in the second observed year led to an increase in GPP $(5 \%)$ and NEE $(35 \%) \mathrm{C}$ uptake. The average annual NEE$\mathrm{C}$ uptake of the cushion bog $\left(-122 \pm 76 \mathrm{~g} \mathrm{~m}^{-2} \mathrm{a}^{-1}, n=2\right)$ was more than 4 times larger than the average uptake of the moss-dominated bog $\left(-27 \pm 28 \mathrm{~g} \mathrm{~m}^{-2} \mathrm{a}^{-1}, n=2\right)$.

\section{Introduction}

Although peatlands cover a comparably small area of the Earth's land surface, they store large amounts of carbon (Yu et al., 2010). Intact peatlands act as net sinks for atmospheric carbon (C) and play an important role in the terrestrial $\mathrm{C}$ cycle and therefore in the climate system. While in-depth studies of long-term and recent carbon accumulation rates are available for many Northern Hemisphere bogs, carbon flux data from Southern Hemisphere bogs are scarce. The Magellanic Moorland, which covers an area of $44000 \mathrm{~km}^{2}$ of coastal Patagonia in Chile and Argentina, is one of the most notable peatland complexes south of the Equator and belongs to the world's largest wetlands (Fraser and Keddy, 2005). Significant parts of the Magellanic Moorland are dominated by a unique type of bog ecosystem, which is exclusive to the Southern Hemisphere. These socalled cushion bogs are rainwater-fed peatland ecosystems, 
which are dominated by the vascular plants Astelia pumila (J. R. Forst.) Gaudich. (Govaerts, 2019) and Donatia fascicularis (J. R. Forst. \& G. Forst.) (Ulloa Ulloa et al., 2017) as opposed to the majority of global bogs, which are commonly peat moss-dominated. Both cushion plants are characterized by high nutrient use efficiency, slow biomass turnover and a large root biomass in relation to the small aboveground part of the plants (Kleinebecker et al., 2008). Fritz et al. (2011) estimated fine root biomass accumulation to be 4 times larger in cushion bogs than in Northern Hemisphere raised bogs. The aerenchymatic roots of vascular cushion plants lead to additional oxygen transport to the rhizosphere and thereby to highly decomposed peat also near the surface and to closeto-zero methane emissions (Fritz et al., 2011; Münchberger et al., 2019).

In this study, we present carbon dioxide $\left(\mathrm{CO}_{2}\right)$ flux time series from two bogs located in southernmost Patagonia on Tierra del Fuego. One site is a peat moss-dominated raised bog, and the other site is a vascular plant-dominated cushion bog. We measured $\mathrm{CO}_{2}$ fluxes continuously for more than 2 years at both sites using the eddy covariance (EC) technique. With the EC method, we were able to measure $\mathrm{CO}_{2}$ net ecosystem exchange (NEE) on ecosystem scale and at high temporal resolution. To date, trace gas exchange fluxes of southern Patagonian bogs have been investigated within three $\mathrm{CH}_{4}$ flux studies using data acquired with manual chamber measurements from the same sites, which we investigated in the study at hand. Fritz et al. (2011) measured $\mathrm{CH}_{4}$ fluxes six times on $3 \mathrm{~d}$ representative for spring, summer and autumn in a cushion bog on the Península Mitre close to the Beagle Channel from where a larger summer data set of $\mathrm{CH}_{4}$ emissions has been presented recently by Münchberger et al. (2019). Lehmann et al. (2016) investigated $\mathrm{CH}_{4}$ fluxes during four summer days from the Río Pipo raised $S$. magellanicum bog near Ushuaia.

Our primary objective in this study is to describe the $\mathrm{CO}_{2}$ flux dynamics of, in this respect, previously unstudied cushion bogs in the most general way feasible. Therefore, we selected a second bog site for comparison, which represents a globally common type of ombrotrophic bog and measured $\mathrm{CO}_{2}$ exchange for more than two vegetation periods at both sites. This approach was thought to enable us to differentiate between variations of the $\mathrm{CO}_{2}$ flux dynamics between cushion bogs and other global bogs that are mainly related to the varying climatic conditions on Tierra del Fuego and variations caused by the diverging traits of cushion plants in comparison to peat mosses. Two years of data help to distinguish between generally valid properties and the effect of a potentially extreme year.

The overriding research question of this study is the following: do the contrasting traits of cushion plants and peat mosses lead to distinct dynamics of primary production and ecosystem respiration both with respect to average annual net $\mathrm{C}$ uptake and in relation to the sensitivity of both bog ecosystems to the variability in environmental driver courses? On that account, our initial objective is to comprehensively describe the $\mathrm{CO}_{2}$ net ecosystem exchange (NEE) flux dynamics of two contrasting bog ecosystems on Tierra del Fuego using an EC setup. We apply a mechanistic modeling approach yielding a partitioned net $\mathrm{CO}_{2}$ flux with two model terms estimating total ecosystem respiration (TER) and gross primary production (GPP) separately. We finally compare our data with literature records of Northern and Southern Hemisphere NEE balances and whole ecosystem $\mathrm{C}$ balances taking into account methane flux data that have been published for the two sites of this study.

\section{Tierra del Fuego: a review on geography, peatland zonation and research history}

\subsection{Geographical setting and climatic gradients}

Tierra del Fuego is an archipelago located at the southern tip of South America between 52 and $56^{\circ} \mathrm{S}$. It is confined by the Strait of Magellan in the north and the Beagle Channel in the south (see Fig. 1). To a large extent, the landscape and vegetation history of Tierra del Fuego during the Holocene is known from bog profiles, which were analyzed for paleogeological and paleoecological studies. They show that the transition from the Pleistocene into the Holocene began as early as 17800 years BP (Rabassa et al., 2000) in the region with glaciers retreating westwards from the terminal moraine location at Punta Moat $\left(55.0^{\circ} \mathrm{S}, 66.8^{\circ} \mathrm{W}\right)$. Around 11000 years BP, flooding of the Beagle Channel by the sea began (Vanneste et al., 2015). Open Nothofagus woodlands and grasslands developed in the lowlands during the early Holocene when precipitation increased. Variability in rainfall was, however, high, enabling the spread of frequent peat and forest fires during drought periods (Markgraf and Huber, 2010). Precipitation variability and thereby the frequency of fire events decreased after around 5000 years BP. Along with a change in species composition, dense Nothofagus forest replaced the former open woodlands (Markgraf and $\mathrm{Hu}-$ ber, 2010). With shorter summer drought periods, the expansion of ombrotrophic Sphagnum bogs was promoted. A climatic shift towards colder, wetter and stormier conditions around 2600 years BP (Heusser, 1995) led to the invasion of Sphagnum-dominated bogs by vascular plants at windexposed areas along the north coast of the Beagle Channel on Península Mitre (see Fig. 1). These present-day cushion bogs are dominated by A. pumila and D. fascicularis.

Today, geographical shifts in general peatland types follow the steep climatic east-west gradient across Tierra del Fuego, which is caused by the mountain ranges of the Andes and the Cordillera Darwin and foremost affects the distribution of precipitation. While winds from the west-northwest prevail year-round on the regional scale, the relief divides southern Patagonia in a very moist western part (up to $5000 \mathrm{~mm} \mathrm{a}^{-1}$ ) and a steppe (below $300 \mathrm{mma}^{-1}$ ) (Tuhkanen, 1992, as re- 
viewed in Holl, 2017). However, local precipitation and wind conditions can be heavily influenced by smaller-scale relief features of the landscape. At the Pacific coast on Isla de los Evangelistas $\left(52^{\circ} 24^{\prime} \mathrm{S}, 75^{\circ} 06 \mathrm{~W}\right)$ for example, the average annual wind speed is $12 \mathrm{~m} \mathrm{~s}^{-1}$ coming from the northwest, whereas Ushuaia experiences mainly southwesterly winds with an annual average of around $4 \mathrm{~m} \mathrm{~s}^{-1}$ (Tuhkanen, 1992). In general, winds are stronger in spring and summer than in winter. Plant ecology is, however, not mainly impacted by the speed of the winds but by the constancy with which they sweep across the region. The fact that the strongest winds occur in summer distinguishes southern Patagonia from the midlatitudes of the Northern Hemisphere (Weischet, 1985) and puts particular pressure on plants as their trade-off between transpiration and photosynthesis potentially becomes less beneficial in terms of net $C$ gain during the windy vegetation period. Setting the Magellanic Moorland further apart from Northern Hemisphere peatlands and northern ecosystems in general is the low input of airborne anthropogenous pollutants and nutrients. With the westerlies blowing across southern Patagonia from the open Pacific year-round and due to little agriculture in the region, significant sources of, for example, heavy metals or nitrogen compounds are comparably far away. Some authors have stressed the importance of Fuegian ecosystems as a basal reference to their anthropogenically altered global counterparts. Studying these landscapes allows for a "glimpse of pre-industrial environments" as Kleinebecker et al. (2008) put it in their biogeochemical analysis of peat samples from a west-east Andean transect $\left(53^{\circ} \mathrm{S}\right)$. Fritz et al. (2011) estimated nitrogen deposition at the north coast of the Beagle Channel to be very low at $0.1 \mathrm{~g} \mathrm{~m}^{-2} \mathrm{a}^{-1}$ inferring this number from data published by Godoy et al. (2003) about the Pacific coast of Chilean Patagonia.

In this study, we investigated two ombrotrophic bog sites on Isla Grande de Tierra del Fuego (see Fig. 1), both close to the north coast of the Beagle Channel and situated on Argentinean territory. Despite profound similarities between the two ecosystems (both are rainwater-fed, peat-accumulating mires), they are dominated by contrasting vegetation communities and occur in different geomorphological settings. According to the vegetation zonation of Moore (1983), one site belongs to the cushion bogs of the Magellanic Moorland zone, the other one to the Sphagnum bogs of the deciduous forest zone.

\subsection{Fuegian peatland types}

The Fuegian landscape as a whole has been termed Magellanic Moorland or Magellanic tundra complex (Pisano, 1977, 1983, as reviewed in Holl, 2017) and in particular consists of extended wetland areas interlinked with forests. The Magellanic Moorland covers an area of $44000 \mathrm{~km}^{2}$ (Arroyo et al., 2005) of which $2700 \mathrm{~km}^{2}$ are located on Argentinean territory (Iturraspe, 2012). In the dry northern and central Isla
Grande de Tierra del Fuego, seasonally flooded vegas that lack the presence of peat mosses can be found. Raised Sphagnum magellanicum bogs are distributed throughout the central and marginal cordilleran valleys and roughly follow the distribution of Nothofagus pumilio forests (Tuhkanen, 1990, as reviewed in Holl, 2017). Cushion bogs dominate the wet Pacific coast but also extensive parts of Península Mitre in the east of Isla Grande and the archipelagic region south of the Beagle Channel on Chilean territory on Isla Navarino.

Cushion bogs form a unique type of peatland, exclusively found on the Southern Hemisphere. They grow in similar relief settings like, for example, Atlantic blanket bogs in Ireland. Their main peat forming species, however, are not mosses but the vascular plants $D$. fascicularis and A. pumila. Phylogenetically, A. pumila belongs to the family of Asteliaceae in the order of Asparagales. The genus Astelia was established by Joseph Banks and Daniel Solander in 1810. A. pumila is a perennial herb that grows in dense patches and is characterized by a high ratio of belowgroundto-aboveground biomass (Fritz et al., 2011). Its porous roots are commonly longer than $1 \mathrm{~m}$ (Grootjans et al., 2010). With stems of up to $5 \mathrm{~cm}$, the thick and imbricate 1 to $3 \mathrm{~cm}$ long and around $0.5 \mathrm{~cm}$ wide leaves grow relatively close to the ground. They appear dark green and shiny on the upper, paler and duller on the lower side. The leaves are rigid and show apical growth. Despite its occurrence in nutrient-poor environments, high nutrient use efficiency and low biomass turnover enable $A$. pumila to sustain its dense and relatively large root system (Kleinebecker et al., 2008). Due to additional oxygen being transported into the soil through aerenchymatic roots, the accumulated peat is highly decomposed. Fritz et al. (2011) report humification grades of H8 to H10 on the von Post scale (von Post, 1922) and estimated that cushion bog plants accumulate up to 4 times more fine root biomass compared to rates from the Northern Hemisphere ombrotrophic bog ecosystem reported by Moore et al. (2002).

The raised Sphagnum bogs of the cordilleran valleys on Tierra del Fuego are more similar to Northern Hemisphere bogs. Biodiversity in these systems is, however, very low in comparison to their northern counterparts. They can be inhabited by as little as 10 vascular plant species (Moen et al., 2005). Their vegetation community consists nearly completely of one moss species: Sphagnum magellanicum. Apart from that, only two other peat mosses commonly occur in transitions to fens (S. fimbriatum or in pools (S. cuspidatum) as stated by Kleinebecker et al. (2007).

Data on the occurring peatland types and their distribution across Tierra del Fuego have been gathered and compiled, for example, by Roivainen (1954), Auer (1965), Pisano (1983), Tuhkanen (1990), Rabassa et al. (1996), Roig et al. (2001), Blanco and de la Balze (2004), Moen et al. (2005), Mauquoy and Bennett (2006), Iturraspe (2010) and Grootjans et al. (2010). In the past, Fuegian peatlands have often been studied by geologists to yield information that they contain on the 


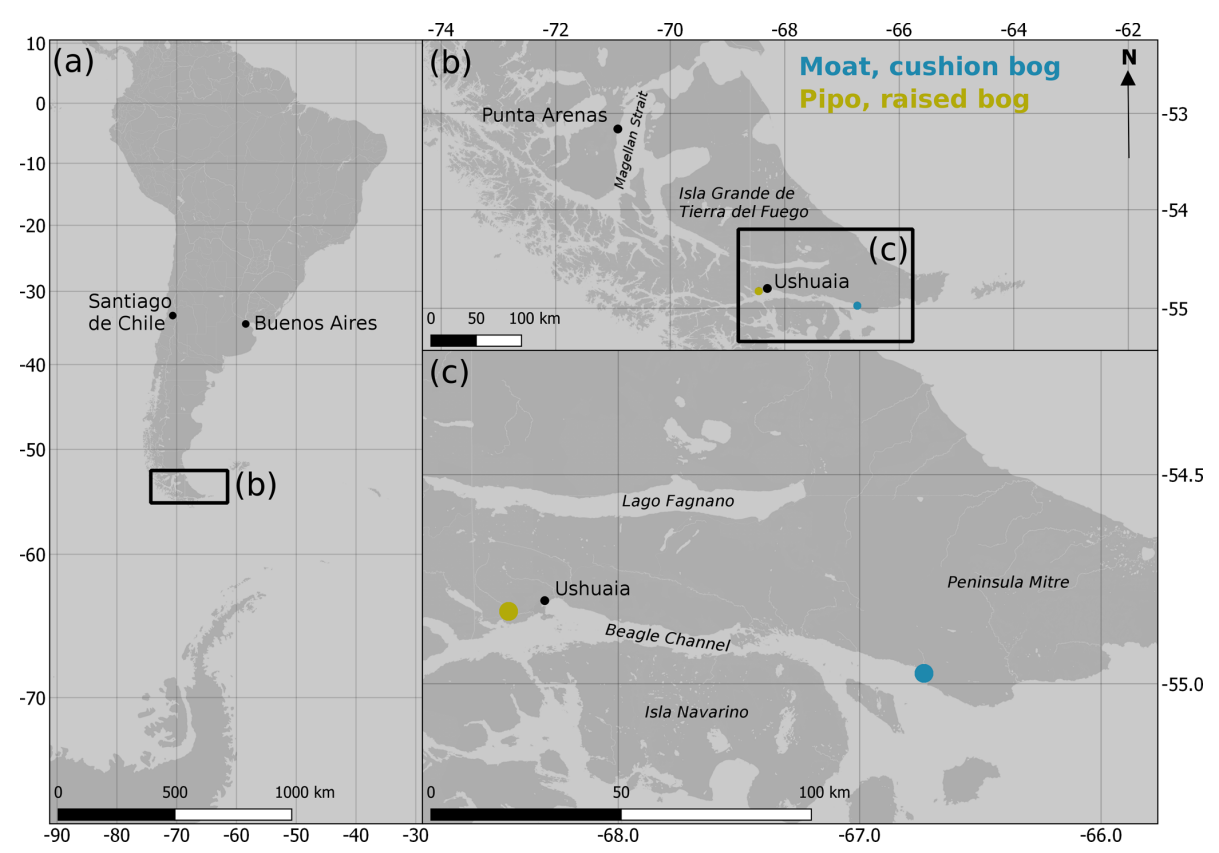

Figure 1. Location of the two measurement sites Moat and Pipo along the northern coast of the Beagle Channel on Tierra del Fuego, Argentina. (Map data: (C) OpenStreetMap contributors 2019. Distributed under a Creative Commons BY-SA License.)

Pleistocene and Holocene periods (e.g., Auer, 1965; Heusser, 1995; Rabassa et al., 1989, 2000, 2006). More recently, the focus of publications in this discipline has shifted towards the east (Península Mitre and Isla de los Estados), beyond the extent of the last glaciation (Heusser, 1995; Björck et al., 2012; Ponce and Fernández, 2014; Ponce et al., 2016). Lately, the interest of ecologists in the scarcely studied peatlands of Península Mitre has grown (Fritz et al., 2011; Iturraspe, 2012; Grootjans et al., 2014; Münchberger et al., 2019) due to their pristine character and their spatial dominance in this part of Isla Grande.

\section{Methods}

\subsection{Site descriptions}

\subsubsection{Moss-dominated raised bog, Pipo}

Río Pipo mire (hereafter Pipo) is located close to the city of Ushuaia at $54.83^{\circ} \mathrm{S}, 68.45^{\circ} \mathrm{W}$ in Parque Nacional Tierra del Fuego, $60 \mathrm{~m}$ above sea level and around $5 \mathrm{~km}$ north of the Beagle Channel. The mire is a raised $S$. magellanicum bog as they are typical for the wind-protected western valleys of Tierra del Fuego (Iturraspe, 2012). It covers an area of around 60 ha at the southern end of a glaciogenic valley bottom. The valley stretches to the southeast and is drained by the river Río Pipo, which marks the northern margin of the bog. Along its southern border, a rather narrow lagg zone forms the transition to the adjacent upwards sloping Nothofagus pumilio forest. S. magellanicum is, with a surface cover of around $40 \%$ (Mark et al., 1995; Lehmann et al., 2016), the most abundant plant species. It occurs in wet lawns and forms roughly north-south-oriented chains of hummocks perpendicular to the drainage direction. Alternating strips of lawns with pools and hummocks compose most of the peatland's surface. The drier hummocks are commonly covered by the dwarf shrub Empetrum rubrum and the rush Marsipospermum grandiflorum (Lehmann et al., 2016). We found the peat base between 3.8 and $4.3 \mathrm{~m}$ below the surface within four peat cores that we drilled at different microtopographical positions.

The literature account of mean annual precipitation for Ushuaia ranges from $530 \mathrm{~mm}$ (Iturraspe, 2012), over $545 \mathrm{~mm}$ (Pisano, 1977) to $574 \mathrm{~mm}$ (Tuhkanen, 1992). At a central point in the peatland, we measured $515 \mathrm{~mm}$ cumulative precipitation between 1 March 2016 and 28 February 2017, between $3 \%$ and $11 \%$ below the literature averages. During the same period, the cumulative evapotranspiration determined with our equipment amounted to $706 \mathrm{~mm}$, making water stress a considerable issue for plants in 2016. Due to energy supply outages, our precipitation records for the remainder of 2017 and 2018 are incomplete. Precipitation sums measured by the Argentinean Servicio Meteorológico Nacional (SMA) at Ushuaia airport (2016: $334 \mathrm{~mm}$; 2017: $418 \mathrm{~mm}$ ), which is located around $4 \mathrm{~km}$ outside of the city center of Ushuaia on a peninsula in the Beagle Channel and close to Centro Austral de Investigaciones Científicas (CADIC) in the city of Ushuaia (2016: $462 \mathrm{~mm}$; 2017: $520 \mathrm{~mm}$; personal communication by Gastón Kreps) also suggest that 2016 was a comparably dry year. Deviations between those sums on the 
one hand demonstrate the high variability of local precipitation in the region. On the other hand, sensor bias related to the windy conditions at the exposed airport site or to the lack of an accurate representation of precipitation as snow could have contributed to this deviation.

The mean annual temperature at a long-term meteorological station in Ushuaia is $5.5^{\circ} \mathrm{C}$ (Iturraspe, 2012). In 2017, we measured an annual mean air temperature of $5.3^{\circ} \mathrm{C}$. Mean June air temperatures were $5.8^{\circ} \mathrm{C}$ in 2016 and $0.0^{\circ} \mathrm{C}$ in 2017. Compared to the long-term average June temperature of $1.2^{\circ} \mathrm{C}$ given by Iturraspe (2012), the winter of 2016 was particularly warm, whereas June of 2017 was closer to the mean. Maximum annual air temperatures occurred on 26 March $2016\left(21.7^{\circ} \mathrm{C}\right)$ and on 6 November $2017\left(22.1^{\circ} \mathrm{C}\right)$, minimum air temperatures on 18 August $2016\left(-5.6^{\circ} \mathrm{C}\right)$ and on 17 June $2017\left(-8.1^{\circ} \mathrm{C}\right)$. During both years, wind came almost exclusively from west-northwestern directions, hence from the valley.

\subsubsection{Vascular plant-dominated cushion bog, Moat}

The second site (hereafter Moat) is located close to Bahía Moat at $54.97^{\circ} \mathrm{S}$ and $66.73^{\circ} \mathrm{W}$. The bay is formed by the creek Río Moat that drains towards the south into the Beagle Channel at the southwestern edge of Península Mitre. Our measurements were conducted in a cushion bog approximately $1 \mathrm{~km}$ off the Beagle Channel's northern coast, which developed on a series of three glaciofluvial plains elevated between 33.1 and $40.3 \mathrm{~m}$ above mean sea level (Borromei et al., 2014). The bog is limited by Río Moat in the west and a Pleistocene fronto-lateral moraine in the south (Borromei et al., 2014). It is sickle-shaped, covers an area of 170 ha and slopes at $0.6^{\circ}$ slightly towards the southeast. In the north, the mire is bordered by a subantarctic evergreen forest dominated by Nothofagus betuloides and Drimys winteri (Heusser, 1995) interlinked with S. magellanicum peatlands. The cushion bog drains into a channel in the north that partly runs belowground and receives water from both the bog and a hill in the north. The outflow channel joins with several other creeks further east before discharging into the Beagle Channel around $4 \mathrm{~km}$ southeast of Bahía Moat.

More than $70 \%$ (Fritz et al., 2011) of the bog's surface is covered by the evergreen cushion plants A. pumila and D. fascicularis that form dense and firm lawns. They occur together with Caltha dioneifolia, C. appendiculata, Carex antarctica, Drosera uniflora, Empetrum rubrum, Tetroncium magellanicum and stunted Nothofagus spp. Although the microrelief of this landscape is not very pronounced, a pattern of cushions and small ponds has developed (Blanco and de la Balze, 2004). Small areas, often on the somewhat windprotected edges of pools, are dominated by $S$. magellanicum. In the peat profile, however, remnants of $S$. magellanicum make up large parts of the material under areas that cushion plants dominate today. We found Sphagnum peat from the peat base at 7 until $4.2 \mathrm{~m}$ below the surface. From 4.2 to
$2.2 \mathrm{~m}$, thin layers of alternating decomposition grade and detritus amount that lack cushion plant remnants occur. From $2.2 \mathrm{~m}$ to the surface, the substrate consists of highly decomposed A. pumila peat. At the same site, other studies report similar results. Heusser (1995) found A. pumila residuals until $1.7 \mathrm{~m}$ below the surface; Fritz et al. (2011) report Sphagnum peat at depths greater than $3 \mathrm{~m}$. Borromei et al. (2014) give a peat depth of $9.96 \mathrm{~m}$ that the authors date at $9.750 \pm 40$ years BP. Long-term weather data are not available for Punta Moat. With our setup, we measured $576 \mathrm{~mm}$ cumulative rainfall between 1 February and 31 December 2016 and an annual precipitation of $726 \mathrm{~mm}$ in 2017. Mean annual air temperature was $6.27^{\circ} \mathrm{C}$ in 2016 (February to December) and $6.38^{\circ} \mathrm{C}$ in 2017. Mean June air temperature was considerably higher in $2016\left(5.41^{\circ} \mathrm{C}\right)$ than in $2017\left(2.07^{\circ} \mathrm{C}\right)$. With a mean February value of $8.90^{\circ} \mathrm{C}$ in 2016 and $10.35^{\circ} \mathrm{C}$ in 2017 summer air temperatures were more similar between the years. The highest air temperatures were measured on $26 \mathrm{March}\left(22.44^{\circ} \mathrm{C}\right)$ in 2016 and on 6 November $\left(22.48^{\circ} \mathrm{C}\right)$ in 2017 , and the coldest air temperatures were measured on 2 July $\left(-4.18^{\circ} \mathrm{C}\right)$ in 2016 and on 17 June $\left(-7.53^{\circ} \mathrm{C}\right)$ in 2017.

\subsection{Instrumentation}

Each eddy covariance (EC) system we used to estimate turbulent $\mathrm{CO}_{2}$ fluxes consisted of a 3-D sonic anemometer (WindMaster Pro, Gill, UK), an infrared gas analyzer and a data logger (LI-7200 and LI-7550; LI-COR, USA). Additional atmospheric variables were recorded on a separate data logger (CR3000; Campbell Scientific, UK). Air relative humidity and temperature were measured with an HC2-S3 probe (Rotronic, Switzerland), photosynthetically active radiation (PAR) with an SKP 215 sensor (Skye Instruments, UK) and precipitation with an ARG100 rain gauge (EML, UK). The instrumental setup was identical at both sites. Gas concentrations and three-dimensional wind velocity raw data were logged at $20 \mathrm{~Hz}$ between 31 January 2016 and 17 May 2018 in Moat and between 8 February 2016 and 17 April 2018 in Pipo. Biomet data were recorded at $1 \mathrm{~Hz}$ within the same time spans. Both LI-7200 analyzers were running on factory calibration until 11 November 2017 (Moat) and 9 November 2017 (Pipo), were zero- and spancalibrated and restarted on 17 November 2017 (Moat) and 16 November 2017 (Pipo). Energy to run the equipment was generated on-site with a wind turbine (LE-600; Leading Edge, UK; peak power $600 \mathrm{~W}$ ) and two photovoltaic panels (OS-172; Leading Edge, UK; peak power $85 \mathrm{~W}$ ). 


\subsection{Data processing}

\subsubsection{Flux calculation and quality filtering}

We used the EC technique to determine half-hourly gas and energy fluxes from the high-frequency raw gas concentration and three-dimensional wind velocity time series. A comprehensive description of the EC approach is given, for example, by Aubinet et al. (2012). Half-hourly turbulent $\mathrm{CO}_{2}$ fluxes were computed using the software EddyPro 6.2.0 (LICOR, USA) and included the following standardized steps; see Holl (2017); Holl et al. (2019).

We detected and removed raw data spikes according to Vickers and Mahrt (1997), with a maximum of $1 \%$ accepted spikes and a maximum of three samples as consecutive outliers. Because we used anemometers that were affected by a firmware bug (published as Technical Key Note KN1509v3 by Gill Instruments), we compensated for the apparent underestimation of the vertical wind speed measurement by instructing EddyPro to apply the multiplication factor given in the mentioned publication. Moreover, due to the use of Gill anemometers, we applied an angle of attack correction, i.e., a compensation for flow distortion induced by the anemometer frame (Nakai et al., 2006). Coordinate rotation to align the anemometer $x$ axis to the current mean streamlines was calculated as double rotation according to Kaimal and Finnigan (1994) and linear detrending as proposed by Gash and Culf (1996). With simultaneously available water vapor concentration, cell temperature and cell pressure measurements from the LI-7200 gas analyzer, $\mathrm{CO}_{2}$ concentrations could be converted directly into mixing ratios, i.e., concentrations referring to dry air of constant temperature (Ibrom et al., 2007b; Burba et al., 2012), making corrections for air density fluctuations unnecessary.

To determine time lags between the water vapor concentration measurements and the vertical wind speed time series, we used the automatic time lag optimization option in EddyPro. For this procedure, prior to processing the complete data set, time lags were determined for subperiods of raw data with varying instrumental setup by covariance maximization (Fan et al., 1990). A searching window around the median of the found time lags (nominal time lag, $T_{\text {nom }}$ ) is defined by $T_{\text {nom }} \pm 3.5 \times$ MAD, where MAD is the median absolute deviation of the found time lags. When processing the complete data set, EddyPro performed a covariance maximization of vertical wind speed and the scalar of interest for each half hour and then checked whether the found time lag fell within the searching window defined before. If not, $T_{\text {nom }}$ was used as time lag. Water vapor concentration time series were binned in 10 relative humidity classes. The procedure was applied to each class, resulting in 10 different nominal time lags. Time lags between the $\mathrm{CO}_{2}$ concentration and vertical wind speed time series were estimated by covariance maximization. We calculated time lag statistics and a nominal time lag using the above described option in EddyPro.
$\mathrm{CO}_{2}$ time lags were not divided in different humidity classes. We addressed time lag statistics later during quality filtering.

We corrected for low-frequency loss due to finite averaging time and linear detrending as described by Moncrieff et al. (2004). In order to obtain a correction factor for each flux value, EddyPro estimated true cospectra as proposed by Kaimal et al. (1972) and reformulated by Moncrieff et al. (1997) for each half hour. We set EddyPro to remove highfrequency noise from the gas concentration spectra before continuing with the spectral attenuation estimation. In this step, a lower limit of the expected high-frequency noise was user-set. The software then linearly interpolated between this lower limit and the highest available frequency $(20 \mathrm{~Hz})$ in the $\log -\log$ transformed spectrum and subtracted this function from the spectrum's high-frequency part. Lower limits were set to $5 \mathrm{~Hz}$ for $\mathrm{CO}_{2}$ and water vapor concentration spectra. After noise removal, frequency-wise multiplication with a transfer function yielded an estimate of the filtered signal in the frequency domain. The transfer function was selected by EddyPro according to the detrending method used as given by Moncrieff et al. (2004). After integrating over the averaging period, a low-cut spectral correction factor for each raw flux was calculated.

We accounted for high-frequency loss due to path averaging, signal attenuation and finite time response of the instruments using the method of Fratini et al. (2012). EddyPro first determined the cut-off frequency $\left(f_{\mathrm{c}}\right)$ and natural frequency $\left(f_{\mathrm{n}}\right)$ by fitting the amplitude response of a first-order lowpass filter $\left(H_{\text {IIR }}\left(f_{\mathrm{n}} / f_{\mathrm{c}}\right)\right)$ to power spectrum ensembles of the respective scalar time series. For water vapor, $f_{\mathrm{c}}$ was estimated for nine relative humidity classes. Correction factors $F 1$ were calculated with two methods depending on sensible and latent heat fluxes being above (high fluxes) or below (low fluxes) the thresholds of 10 and $5 \mathrm{~W} \mathrm{~m}^{-2}$ respectively (Fratini et al., 2012). For high fluxes, EddyPro calculated the correction factors as proposed by Hollinger et al. (1999). F1 estimation included the degradation of the unattenuated sensible heat flux cospectrum by multiplying it with $H_{\mathrm{IIR}}\left(f_{\mathrm{n}} / f_{\mathrm{c}}\right)$ for the previously determined $f_{\mathrm{c}}$. For low fluxes, the obtained $F 1 f_{\mathrm{c}}$ data set was fitted to the model given by Ibrom et al. (2007a) for stable and unstable conditions. We performed cut-off frequency and function parameter estimation on ensembles of (co)spectra separately for two subperiods that we divided at the calibration date (see Instrumentation section). Before using them for ensemble spectra estimations, the (co)spectra were quality filtered using the scheme of Vickers and Mahrt (1997) and by omitting the half hours that were assigned quality class 2 according to Mauder and Foken (2004). We corrected for spectral losses due to crosswind and vertical separation between the LI-7200 tube intake and the anemometer in EddyPro following Horst and Lenschow (2009). Additionally, we set EddyPro to calculate random flux uncertainty estimates (Finkelstein and Sims, 2001) and three quality flags as proposed by Mauder and Foken (2004), which represent flux quality in values from 0 to 2 , with 0 
denoting the highest quality class. This quality evaluation is based on tests for stationarity and developed turbulence, and it thereby indicates whether general EC assumptions about atmospheric conditions were met during a flux calculation period.

We performed the following sequence of quality-filtering steps on the $\mathrm{CO}_{2}$ fluxes: we evaluated sensor diagnostics by using the relative signal strength indication (RSSI) logged from the gas analyzer. Fluxes associated with RSSI values below 65 were discarded. Furthermore, we excluded fluxes when a half-hourly time lag, determined with covariance maximization, fell outside the time window around $T_{\text {nom }}$ that was defined by running the automatic time lag optimization routine in EddyPro (see above). $T_{\text {nom }}$, as well as the window size, was determined for subperiods of different analyzer calibration states. To remove remaining outliers, we defined a range of accepted fluxes by using the 0.1 st and 99.9th percentile of the Mauder and Foken (2004) quality class 0 and 1 fluxes as thresholds.

\subsubsection{Net ecosystem exchange partitioning model}

Unintentional as well as maintenance-related system outages and quality filtering of the calculated $\mathrm{CO}_{2}$ fluxes led to gaps in the net ecosystem exchange (NEE) data sets. The time series from Moat spans 40176 half hours with about $12 \%$ missing records. The Pipo time series is comprised of 38353 30 min steps containing $46 \%$ NEE gaps, and this higher percentage of gaps is mainly related to more frequent power outages due to insufficient input through the wind turbine and the photovoltaic panels. To be able to calculate annual $\mathrm{C}$ balances from the measured NEE data sets, we gap filled the half-hourly time series with a mechanistic modeling approach. We fitted the function given by Runkle et al. (2013) to our NEE, air temperature and radiation data. This bulk model approach is based on the combination of a hyperbolic light saturation function (Thornley, 1998; Zheng et al., 2012) to represent photosynthesis and an exponential temperaturerespiration relation (Van't Hoff, 1898). At times of missing NEE observations, the estimated model parameters can be used together with temperature and PAR data to estimate NEE fluxes. Moreover, the net flux can be partitioned in its components' total ecosystem respiration (TER) and gross primary production (GPP).

$$
\begin{aligned}
\operatorname{NEE}(T, \mathrm{PAR}) & =R_{\mathrm{base}} \times Q_{10}^{\frac{T-T_{\mathrm{ref}}}{\gamma}}-\frac{P_{\max } \times \alpha \times \mathrm{PAR}}{P_{\max }+\alpha \times \mathrm{PAR}} \\
& =\operatorname{TER}(T)+\operatorname{GPP}(\mathrm{PAR})
\end{aligned}
$$

We optimized the four parameters maximum photosynthetic rate $P_{\max }$, base respiration $R_{\text {base }}$ (both in $\mu \mathrm{mol} \mathrm{m}^{-2} \mathrm{~s}^{-1}$ ), temperature sensitivity coefficient $Q_{10}$ and initial quantum yield $\alpha$ (both dimensionless) using a non-linear least absolute residuals method in MATLAB (version 9.5). This algorithm is comparable to a traditional non-linear least squares method; the cost function that is minimized during optimization is, however, not the sum of squared but of absolute residuals, reducing the effect of outliers. We used air temperature $T\left({ }^{\circ} \mathrm{C}\right)$ and photosynthetically active radiation PAR $\left(\mu \mathrm{mol} \mathrm{m} \mathrm{m}^{-2} \mathrm{~s}^{-1}\right)$ as independent variables and the qualityfiltered $\mathrm{CO}_{2}$ fluxes of Mauder and Foken (2004) classes 0 and 1 as dependent variable NEE. We set the reference temperature $T_{\text {ref }}$, at which TER $\left(T_{\text {ref }}\right)=R_{\text {base }}$, to $15^{\circ} \mathrm{C}$ and $\gamma$ to $10^{\circ} \mathrm{C}$ following Runkle et al. (2013) and Mahecha et al. (2010). We divided the measured time series in 1,2 and $5 \mathrm{~d}$ intervals and estimated a set of four parameters for each time window. We used bounds ( $P_{\max }$ : [0 30]; $\alpha$ : [0 0.05]; $R_{\text {base }}:\left[0\right.$ 5]; $Q_{10}$ : [1 $3])$ and start points $\left(P_{\max }: 5 ; \alpha: 0.02 ; R_{\text {base }}: 1.5 ; Q_{10}: 1.4\right)$ to constrain parameter optimization. Parameter uncertainty was estimated using their $95 \%$ confidence bounds.

In addition to the estimation of NEE fluxes at times when filtered observed fluxes were not available, the bulk modeling approach allows for a decomposition of the net $\mathrm{CO}_{2}$ flux in contributions related to photosynthesis and respiration. Before using the bulk model parameter estimates (see Eq. 1) for the calculation of modeled NEE, GPP and TER time series, we quality filtered the parameter time series and applied smoothing functions to them. We rejected all parameters of a time window when any of the parameter uncertainty estimates were larger than the respective parameter value itself, or the algorithm could not ascertain an error estimate indicating a parameter value being stuck at its upper or lower bound during iterative optimization. To smooth the parameter time series, we used a locally weighted regression (Lowess or Loess) method (Cleveland, 1979) in MATLAB. Lowess fitting yields new estimates for the input data that are closer to being members of a continuous function than the input series. Lowess smoothing is a stepwise process during which a linear function is fitted to subsets of data around one focal point for which a new value is estimated as the output of the fitted function. Line-fitting comprises the assignment of weights to all used points that increase with their distance from the focal point along the $x$ axis (time). The use of second-order polynoms for locally weighted regressions is commonly denoted by the slightly differing abbreviation Loess. We used Loess smoothing and quality-filtered results from bulk model estimates of $2 \mathrm{~d}$ windows for all parameter time series except for $Q_{10}$ for which we used $5 \mathrm{~d}$ window bulk models and firstorder polynoms during smoothing. The number of points included in each polynom fit during Lowess or Loess is referred to as span and was always set to $30 \%$ of all available points. As quality filtering of the bulk model parameter estimates resulted in unequally spaced parameter time series, we interpolated the smoothed parameter values linearly to $1 \mathrm{~d}$ intervals before driving the bulk models.

We assume that seasonal changes in plant-physiological characteristics are more likely to follow a continuous function than to exhibit rapid variations. Our method of smoothing the bulk model parameter time series is effective in the removal of noise introduced by bulk model fitting that leads to 
scattering in the parameter time series. Noise characteristics do change with the window size used during bulk model fitting, and larger windows lead to less scatter. Window size is then acting as a low-pass filter that potentially smears up possibly inherent parameter changes on shorter timescales that are, in contrast, still intact after Lowess or Loess smoothing. Shorter-term variations, for example synoptic-scale changes of environmental conditions, can lead to short-term adaption of plants that should be reflected in bulk model parameter time series. The changes in Moat $P_{\max }$ curvature in summer of 2016-2017 (see Fig. 2) are an example of the smoothed parameter series' abilities to reflect inter-annual variations of the seasonal parameter course, in this case a prolonged phase of unusually cloudy conditions in Moat during early summer in December (see Appendix, Fig. C1).

To estimate a PAR value at which the canopy photosynthetic potential was reduced to $1 / 10$ of its initial value $\alpha$, and therefore near saturation, we calculated $\mathrm{PAR}_{\text {sat }}$ as

$\operatorname{PAR}_{\text {sat }}\left(P_{\max }, \alpha\right)=\frac{P_{\max }}{\alpha}+\frac{\sqrt{4 \frac{P_{\max }^{2}}{\alpha^{2}}-4 P_{\text {max }}^{2}\left(\frac{1-z_{\text {sat }}}{\alpha^{2}}\right)}}{2}$,

using the previously determined $P_{\max }$ and $\alpha$ time series at $1 \mathrm{~d}$ intervals and an attenuation factor $z_{\text {sat }}$ of 10 . To set up Eq. (2), we differentiated Eq. (1) with respect to PAR and set it equal to a by $1 / 10$ attenuated quantum use efficiency. We solved this equation for PAR to calculate PAR $_{\text {sat }}$ time series for both sites. Details are given in Appendix D.

\subsubsection{Processing of ancillary meteorological variables}

Before the half-hourly NEE simulations, we filled gaps in the 30 min PAR and air temperature records. We applied a mean diurnal variation method similar to the approach of Falge et al. (2001), which exploits the commonly high autocorrelation of these meteorological variables. Missing values were replaced by averages of available records at the same hour of the day within increasing time windows between 1 and $7 \mathrm{~d}$ around a gap. Window size was increased until at least one record could be found. If more than one record was available, an average was used to fill the respective gap. Within the Pipo data set, $7 \%$ of meteorological observations were missing, and $92 \%$ of these values were filled with averages. The Moat time series contained $1 \%$ gaps, and in $93 \%$ of all cases more than one record was found within the time window around a gap. Gap filling was mostly $(70 \%)$ performed using $1 \mathrm{~d}$ windows for the Pipo data set and with 1 to $3 \mathrm{~d}$ windows in most cases $(57 \%)$ of the Moat time series.

Data analysis included the calculation of the cumulative temperature and radiation quantities growing degree days (GDD) in degrees Celsius and cumulative photosynthetically active radiation $\mathrm{PAR}_{\text {cum }}$ in moles per square meter $\left(\mathrm{mol} \mathrm{m}^{-2}\right)$. We defined $\mathrm{GDD}_{5}$ as the sum of all positive differences between daily average temperatures and a reference temperature, which we set to $5^{\circ} \mathrm{C}$. GDD 5 was calculated as monthly sums for comparison with monthly respiration sums. We expressed PAR cum as daily sums for comparison with cumulated daily GPP amounts.

\subsubsection{Calculation of annual net ecosystem exchange sums}

We proceeded to drive daily versions of Eq. (1), each comprised of a distinct set of four parameters, with half-hourly, gap-filled radiation and temperature data. We calculated uncertainty estimates $u_{\mathrm{GPP}}, u_{\mathrm{TER}}$ and $u_{\mathrm{NEE}}$ for each modeled GPP, TER and NEE flux based on Gaussian error propagation and representing a $95 \%$ confidence interval. We took the partial derivatives of Eq. (1) with respect to the four parameters as described in the Appendix (Eqs. A1 to A3). We simplified the process by neglecting comparably small random errors in temperature and radiation measurements. We used the root mean square error (RMSE) of the smoothed daily parameter time series and the quality-filtered bulk model parameter assessments as uncertainty estimates for each value of the smoothed parameter series.

The partitioned NEE time series from Moat contains data from 29 months (838d), and the Pipo data set includes records from 27 months $(800 \mathrm{~d})$. For the analysis of annually accumulated fluxes, we only used months for which gapfilled data were available at each half hour of each day. We used these 27 (Moat) and 25 (Pipo) complete months to investigate inter-annual variability at each site as well as general variability between the sites.

We constructed an average annual course from spring (1 September) to winter (31 August) by calculating mean monthly sums of NEE, GPP and TER (see Figs. B1, B2 and B3). Complete monthly records were mostly available from 2 years, and three full monthly records were available for March at Pipo as well as for February, March and April at Moat. We expressed the range of individual monthly sums as standard deviation. In most cases, when $n=2$, this means that the range is expressed as the absolute difference between both values divided by the square root of 2 . To estimate and compare average annual courses of the vertical $\mathrm{CO}_{2}$ balances between both sites, we cumulated the 12 average monthly sums. We also added together the standard deviations related to each of these sums to indicate the impact of variations between years on the annual balances. By adding the monthly range estimates and not using the root of the sum of their squares, we treated them as potentially systematic rather than random variations of annual NEE, GPP and TER sums.

To investigate the effect of changing environmental conditions on the partitioned NEE balances at both sites, we divided the time series into 2 consecutive years that we will term Y1 and Y2 hereafter. Because the observations spanned a bit more than 2 years at both locations, we additionally checked the effect of choosing different start dates for 12 month intervals that represent various versions of $\mathrm{Y} 1$ and Y2. We defined three start dates (Pipo: 1 March and 1 April; 
Moat: 1 February, 1 March and 1 April), yielding two (Pipo) and three (Moat), in large parts overlapping versions of $\mathrm{Y} 1$ and Y2 per site.

Estimated GPP and TER fluxes contain only bulk model results, NEE fluxes include measurement data of quality class 0 and modeled fluxes at times without highest-quality observations. Random uncertainty of the observed fluxes was estimated using the method of Finkelstein and Sims (2001) (see Sect. 3.3.1), and modeled fluxes were assigned the previously determined $u_{\mathrm{GPP}}, u_{\mathrm{TER}}$ and $u_{\mathrm{NEE}}$ values as uncertainty estimates. The uncertainty of the annual balances was calculated by taking the square root of the sum of squared individual 30 min flux uncertainties.

\section{Results and discussion}

\subsection{Quality filtering}

Quality filtering of the measured data resulted in 5\% and $13 \%$ omitted records from Moat and Pipo respectively. Most fluxes (1786 and 3105) were filtered out due to the time lag detection quality filter. Of the remaining 36363 and 22037 points, $81 \%$ and $71 \%$ were of Mauder and Foken (2004) quality class 0 , and $97 \%$ and $95 \%$ were of combined quality classes 0 and 1.

Quality filtering of the bulk model parameter time series resulted in $290 P_{\max }, \alpha$ and $R_{\text {base }}$ values from $2 \mathrm{~d}$ window fits for Moat and 155 for Pipo. Related to the total number of $2 \mathrm{~d}$ windows spanned by the time series, data coverage amounts to $69 \%$ and $34 \%$ for Moat and Pipo respectively. In case of the $5 \mathrm{~d}$ intervals used for the estimation of $Q_{10}$ time series, 85 and 140 values met the quality criteria equaling $84 \%$ and $53 \%$ of all $5 \mathrm{~d}$ intervals within the NEE time series.

\subsection{Bulk model parameter time series}

We applied Lowess or Loess smoothing to the parameter time series and thereby generated new sets of bulk model parameters. Smoothed and original bulk model parameters are compared in Fig. 2. The results generally show good agreement with the highest coefficient of determination $\left(r^{2}\right)$ of 0.8 for $P_{\max }$ at both sites, $r^{2}$ values between 0.5 and 0.7 for $\alpha$ and $R_{\text {base }}$, and lowest $r^{2}$ values of 0.2 in case of $Q_{10}$. Loess/Lowess model uncertainty, estimated as RMSE, ranges between $22 \%$ and $29 \%$ of the respective mean parameter value across both sites and parameter sets. Bias errors, expressed as sum of differences between bulk model and smoothed data points divided by the number of samples, are negative and small for both sites (Pipo: $P_{\max }$ : $-0.03 \mu \mathrm{mol} \mathrm{m}^{-2} \mathrm{~s}^{-1}, \alpha$ : $-0.00008, R_{\text {base }}:-0.01 \mu \mathrm{molm}^{-2} \mathrm{~s}^{-1}$ and $Q_{10}:-0.002$; Moat: $P_{\max }:-0.03 \mu \mathrm{molm}{ }^{-2} \mathrm{~s}^{-1}, \alpha:-0.00006 ; R_{\text {base }}$ : $-0.007 \mu \mathrm{mol} \mathrm{m}{ }^{-2} \mathrm{~s}^{-1}$ and $\left.Q_{10}=-0.003\right)$.

General differences in ecosystem characteristics between the cushion plant-dominated and moss-dominated site are indicated by the lower level of $P_{\max }, R_{\text {base }}$ and $\alpha$ values throughout the course of both years in Pipo. Moreover, the timings of the slope changes within these parameters series demonstrate that cushion plant photosynthetic activity reaches its maximum earlier in summer compared to the moss-dominated community, while inter-annual variations also lead to variations of this time lag. While $P_{\max } \max -$ ima were reached about 6 weeks earlier in Moat (28 November 2016) than in Pipo (13 January 2017) in summer of Y1, Moat $P_{\max }$ maxima (8 January 2018) were about 3 weeks ahead of Pipo (28 January 2018) in summer of Y2. $R_{\text {base }}$ maxima time lags were less pronounced and amounted to about $10 \mathrm{~d}$ in $\mathrm{Y} 1$. In contrast to the timing of $P_{\max }$ maxima, $R_{\text {base }}$ maxima were reached earlier at Pipo. In summer of Y2, Moat and Pipo base respiration developed virtually concurrently. While $Q_{10}$ Lowess estimates are the least certain compared to the three other parameters, smoothing reveals a contrasting, mirrored behavior of the sensitivity of respiration to temperature changes between both sites. While $Q_{10}$ maxima occur in winter and minima in summer throughout all years in Moat, Pipo $Q_{10}$ reaches its maxima in summer and its minima in winter. However, the $Q_{10}$ value ranges we found are small, which is in line with results from Mahecha et al. (2010), who reported that ecosystem level temperature sensitivity of TER is with $1.4 \pm 0.1$ rather stable across different global ecosystems.

\subsection{Flux gap filling and partitioning}

After Lowess or Loess smoothing, we interpolated the bulk model parameter time series to equally spaced $1 \mathrm{~d}$ intervals and proceeded to drive those daily models with half-hourly meteorological data. We used the resulting NEE time series to gap fill the observed data sets enabling us to estimate annual vertical partitioned $\mathrm{CO}_{2}$ balances of both bogs. The gap-filled NEE data sets consist of quality class 0 measured fluxes and 26\% (Moat) and 59\% (Pipo) modeled fluxes. Agreement between eddy covariance net $\mathrm{CO}_{2}$ fluxes and modeled fluxes is high while RMSEs are low (Moat: $0.74 \mu \mathrm{mol} \mathrm{m}^{-2} \mathrm{~s}^{-1}$; Pipo: $0.50 \mu \mathrm{mol} \mathrm{m}^{-2} \mathrm{~s}^{-1}$ ) as illustrated in Fig. 3. The models can not explain a relatively small amount of measured high positive fluxes at both sites, which could possibly be related to the rapid release of bubbles from ponds (ebullition; e.g., Glaser et al., 2004). Deviations between model and measurement data increase with increasing absolute fluxes and are smaller close to zero. Bias errors (BEs), expressed as sum of differences between measured and modeled data points divided by the number of samples, are positive but low for both sites (Moat: $0.05 \mu \mathrm{mol} \mathrm{m}^{-2} \mathrm{~s}^{-1}$; Pipo: $0.04 \mu \mathrm{molm}^{-2} \mathrm{~s}^{-1}$ ). The much smaller value range of $\mathrm{CO}_{2}$ fluxes from Pipo compared to Moat is also apparent in Fig.3. Furthermore, we determined correlation coefficients between the modeled TER time series and nighttime (PAR $<$ $10 \mu \mathrm{mol} \mathrm{m}^{-2} \mathrm{~s}^{-1}$ ) EC NEE fluxes and found that also this partitioned flux was well explained by our model (Moat: 

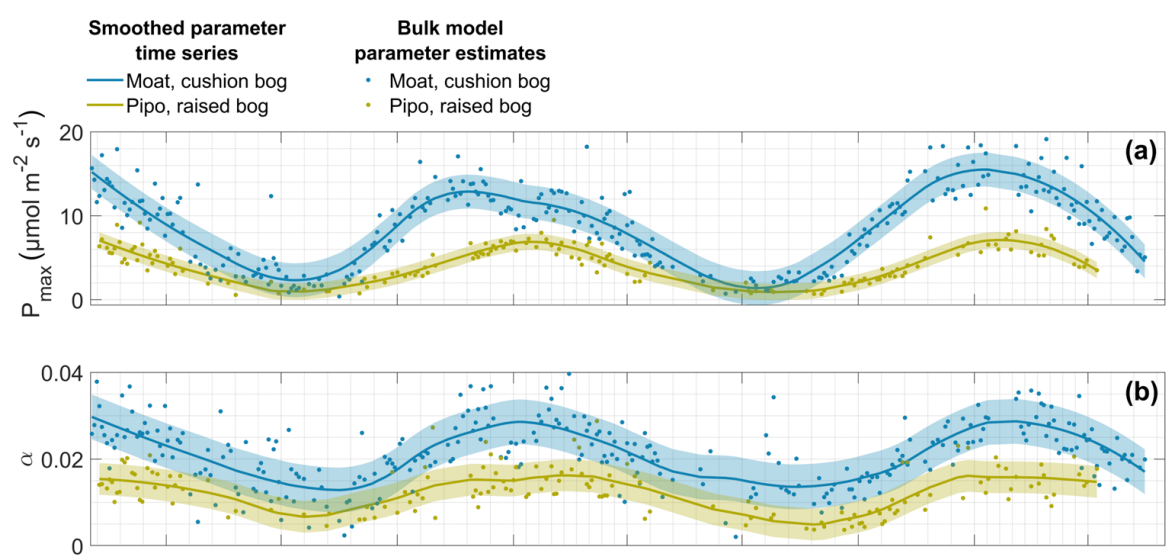

(b)
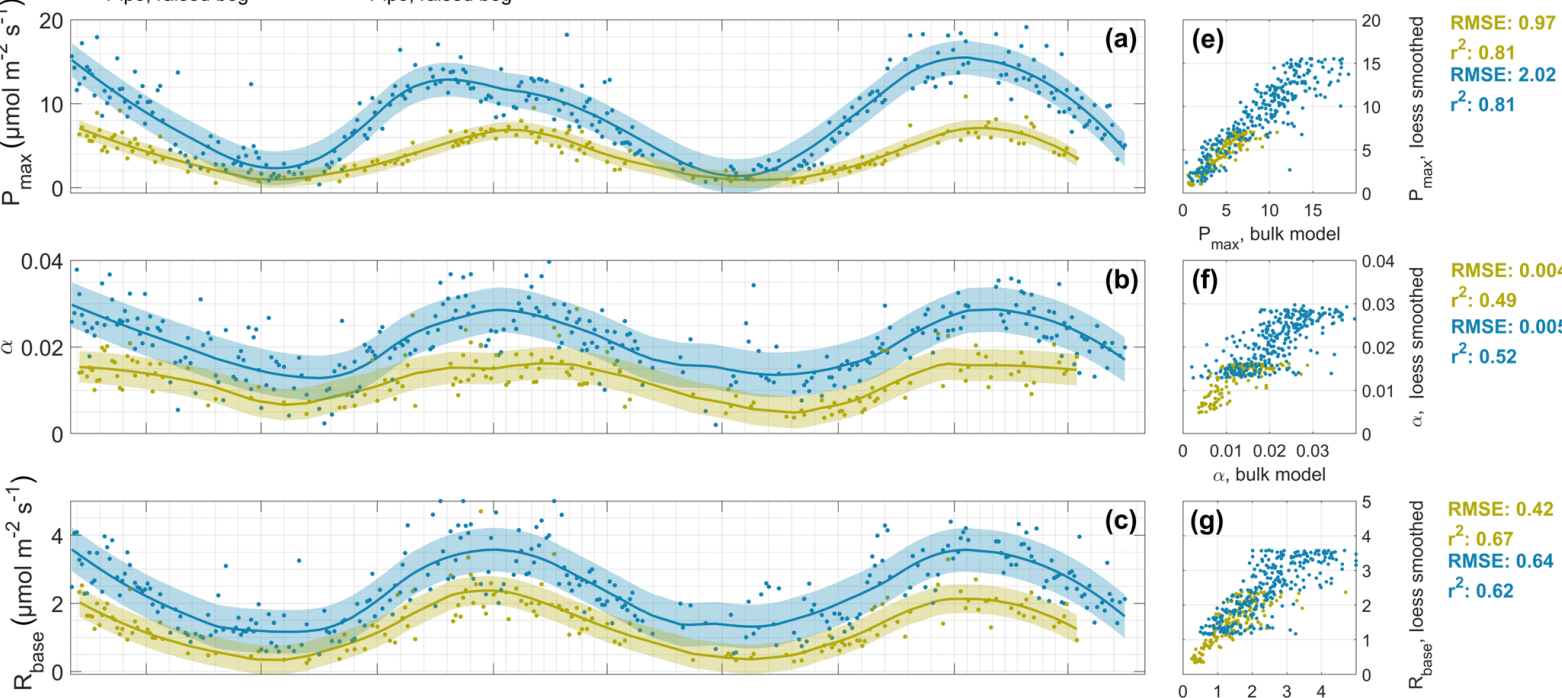

RMSE: 0.004
$r^{2}: 0.49$ RMSE: 0.005 $r^{2}: 0.52$
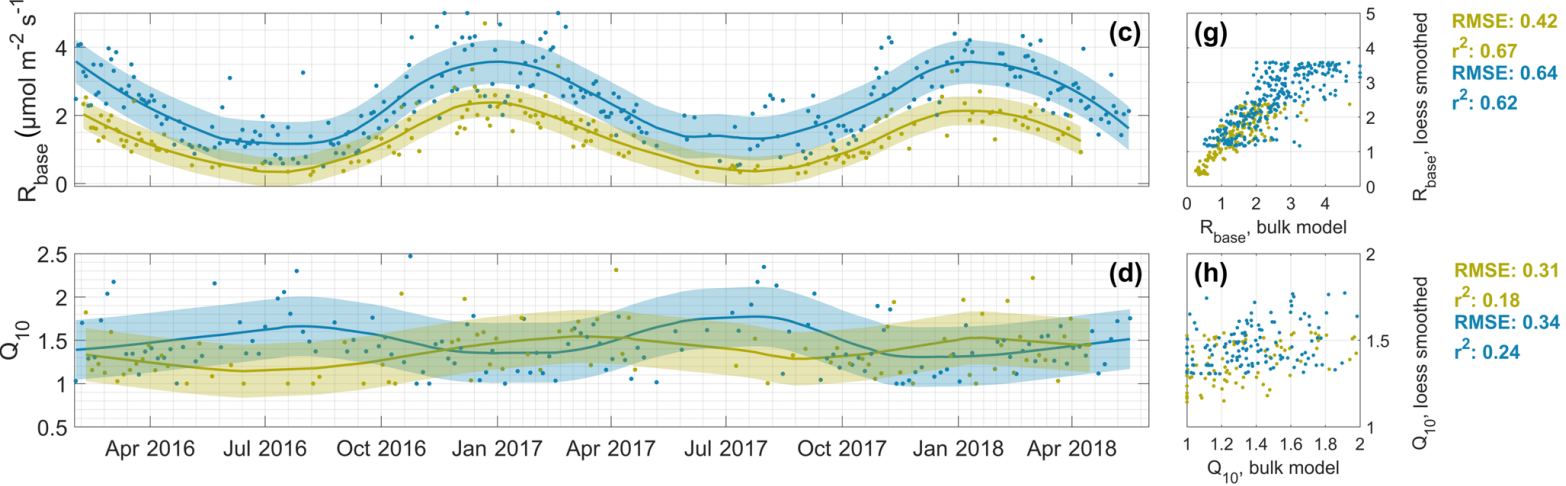

Figure 2. Time series of the parameters maximum photosynthesis $P_{\max }(\mathbf{a})$, initial quantum yield $\alpha(\mathbf{b})$, base respiration $R_{\text {base }}(\mathbf{c})$ and temperature sensitivity $Q_{10}$ (d) that we estimated with $2 \mathrm{~d}$, and in case of $Q_{10}$ with $5 \mathrm{~d}$, window NEE bulk models (dots) and smoothed with a locally weighted regression (Lowess or Loess) method (lines). Areas around lines indicate the uncertainty of smoothed parameter values. Correlations between original bulk model estimates and smoothed values are shown in panels (e) to (h) including the coefficients of determination $\left(r^{2}\right)$ and root mean square error (RMSE).

$r^{2}=0.8, n=14887, \mathrm{RMSE}=0.43 \mu \mathrm{mol} \mathrm{m}^{-2} \mathrm{~s}^{-1}, \mathrm{BE}=$ $-0.003 \mu \mathrm{mol} \mathrm{m}{ }^{-2} \mathrm{~s}^{-1}$; Pipo: $r^{2}=0.6, n=6081$, RMSE $=$ $\left.0.40 \mu \mathrm{mol} \mathrm{m}^{-2} \mathrm{~s}^{-1}, \mathrm{BE}=-0.08 \mu \mathrm{mol} \mathrm{m}^{-2} \mathrm{~s}^{-1}\right)$.

\subsection{Inter-annual flux and driver variability}

To investigate the inter-annual variability of GPP and TER, we cumulated the modeled half-hourly time series annually for different versions of $\mathrm{Y} 1$ and $\mathrm{Y} 2$ as described above (Sect. 3.3.4). To estimate changes in cumulative NEE fluxes, we used gap-filled EC fluxes and summed them up over the same time periods. We calculated mean annual balances from the different versions of Y1 and Y2 (see Table 1). To put the balances into context with shifts in meteorological drivers of photosynthesis and respiration, we calculated the monthly cumulated temperature and radiation measures $\mathrm{GDD}_{5}$ and PAR $_{\text {cum }}$ (see Figs. $\mathrm{C} 1$ and $\mathrm{C} 2$ in the Appendix).

In 2016, growing season temperatures peaked in March, about 1 month later than in the two other observed summers. This vegetation period shift continued with an unusually warm late summer and autumn and culminated in an extremely warm winter month of June at both sites. Mean
June temperatures at Pipo were $4.6^{\circ} \mathrm{C}$ above the long-term average (Iturraspe, 2012). Only at Pipo, early summer of the next vegetation period (November 2016, still in Y1) was once again warmer than the average. With respect to cumulatively available heat, these temperature variations led to a decrease in $\mathrm{GDD}_{5}$ of around $16 \%$ at Pipo in Y2, whereas $\mathrm{GDD}_{5}$ rose by less than $1 \%$ at Moat, which is located closer to the coast. The raised bog's ecosystem respiration was modulated more strongly by the warmer conditions in Y1 than by photosynthesis that dropped only by around $2 \%$ in Y2. However, photosynthesis was also seemingly promoted by the larger availability of heat in Y1, as despite the cumulative radiation increase by about $4 \%$ in Y2 at Pipo, cumulative $|\mathrm{GPP}|^{1}$ still dropped. The annual PAR sum increased more strongly, by about $10 \%$, at the cushion bog site where we estimated a $5 \%$ rise in cumulative $|\mathrm{GPP}|$. As mentioned before, close to the

\footnotetext{
${ }^{1}$ Following micrometeorological conventions, we use GPP with a negative sign as the associated $\mathrm{CO}_{2}$ flux is directed from the atmosphere towards the surface. We use absolute values to be able to describe a decrease or increase in the process photosynthesis with a decrease or increase in $|\mathrm{GPP}|$.
} 


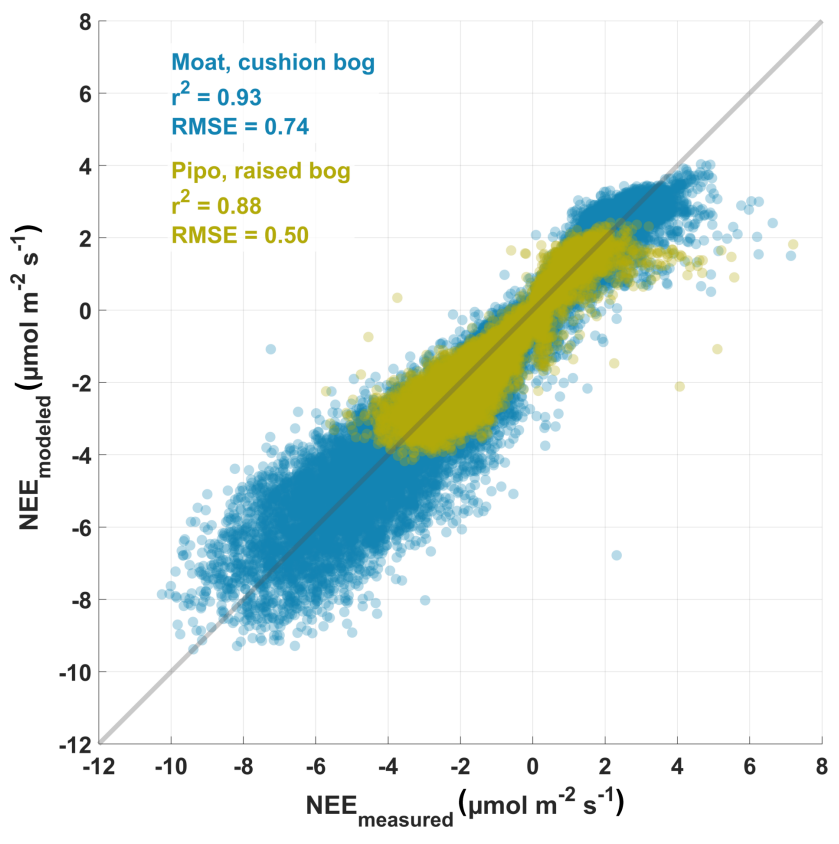

Figure 3. Scatter diagram of modeled half-hourly measured eddy covariance net ecosystem exchange (NEE) fluxes and modeled NEE fluxes, which were derived using Eq. (1). Coefficient of determination $\left(r^{2}\right)$ and root mean square error (RMSE) are given for both investigation sites (Pipo, $n=15903$; Moat, $n=29648$ ).

coast, the summer of Y1 apparently was considerably more cloudy than the subsequent season (see Fig. $\mathrm{C} 1$ in the Appendix). From $\mathrm{Y} 1$ to $\mathrm{Y} 2$, net $\mathrm{CO}_{2}$ uptake increased on average by $35 \%$ in Moat and more than tripled in Pipo. In terms of absolute $\mathrm{CO}_{2}$ uptake increase, the rise at Moat was, however, larger than at Pipo, denoting the fact that $\mathrm{CO}_{2}$ fluxes are on a lower level at Pipo in general. Y1 was an extreme year, especially at Pipo, where prolonged warm temperatures (see Fig. $\mathrm{C} 1$ in the Appendix) and reduced precipitation likely led to dry topsoil conditions that promoted heterotrophic respiration diminishing the ecosystem's $\mathrm{CO}_{2}$ sink function in this year.

The values of all cumulative NEE fluxes and their components that were used to calculate averages from different versions of $\mathrm{Y} 1$ and $\mathrm{Y} 2$, distinguished by various start months, are given in Table 1. The largest difference in annual NEE sums between $\mathrm{Y} 1$ and $\mathrm{Y} 2$ arises in case of the Moat data set when February and March 2016 are excluded from Y1, and accordingly the same months of 2018 are included in Y2. Late summer 2015-2016 was characterized by cool temperatures and less available radiation than summer 2017-2018 when we measured the highest radiation sums and modeled highest cumulative $|\mathrm{GPP}|$ within the observed time series. Excluding an extreme event in the first year and at the same time including a period with an opposite effect on the net $\mathrm{CO}_{2}$ flux in the second year maximizes the differences between both years at both sites. The choice of a particular start month used for summing has a larger impact on annual $\mathrm{C}$ uptake at Moat than at Pipo. While NEE-C uptake changes from $\mathrm{Y} 1$ to $\mathrm{Y} 2$ range from a decrease of $2 \mathrm{~g} \mathrm{~m}^{-2}$ to an increase of $47 \mathrm{~g} \mathrm{~m}^{-2}$ at Moat, the choice of different start months leads to less variability (NEE-C uptake increases from Y1 to Y2 between 23 and $27 \mathrm{~g} \mathrm{~m}^{-2}$ ) at Pipo.

Apart from differences in inter-annual variations of annual NEE sums between the sites, distinctions also arise with respect to the variability of monthly sums from different years. Variations within monthly NEE component sums (see Figs. B1, B2 and B3 in the Appendix) are most pronounced at Moat with respect to GPP and at Pipo with respect to TER. In December, the |NEE|-C differences between 2016 and 2017 are large at both sites (Moat: $32 \mathrm{~g} \mathrm{~m}^{-2}$; Pipo: $15 \mathrm{~g} \mathrm{~m}^{-2}$ ). Although $\mathrm{GDD}_{5}$ was considerably larger only at Moat in December 2017, the relative rise of TER from December 2016 to December 2017 was small $\left(1 \mathrm{~g} \mathrm{~m}^{-2}\right)$. At Pipo, where $\mathrm{GDD}_{5}$ increase was smaller from December 2016 to December 2017, TER-C loss dropped by $8 \mathrm{~g} \mathrm{~m}^{-2}$. November 2016 was particularly warm at Pipo, and the effects might have carried into December. The monthly PAR sum increased from December 2016 to December 2017 at both sites and led to an increase in GPP-C uptake of $33 \mathrm{~g} \mathrm{~m}^{-2}$ at Moat and of $7 \mathrm{~g} \mathrm{~m}^{-2}$ at Pipo. Monthly NEE-C balances of Pipo appear to deviate more intensively from an average annual course when deviations from a mean annual temperature course occur concurrently. At Moat, the GPP response to deviations from the mean in the available amount of PAR has an overriding effect on variations of monthly NEE-C balances. While TER is generally at a higher level at Moat compared to Pipo, interannual temperature variations within months have a less pronounced relative impact on the mean seasonal course of TER.

On average, net $\mathrm{CO}_{2}$ uptake increased substantially at both sites from Y1 to Y2. However, this similar net change resulted from contrasting magnitudes and directions of changes of GPP and TER at both sites. Table 2 gives a simplified, coarsely abstracted overview of the differences in averaged cumulated flux and driver quantities between $\mathrm{Y} 1$ and $\mathrm{Y} 2$ and from site to site; detailed results are given in Table 1 and Figs. $\mathrm{C} 1$ and $\mathrm{C} 2$ in the Appendix. From Y1 to Y2, the magnitude of GPP and TER increased at Moat while $|\mathrm{GPP}|$ and TER decreased at Pipo. The reduction of cumulative respiration at Pipo was, however, larger than the drop in the $|\mathrm{GPP}|$ sum, leading to an increase in annual net $\mathrm{CO}_{2}$ uptake. At Moat, the rise in $|\mathrm{NEE}|$ traces back to an increase in $|\mathrm{GPP}|$ that was larger than the simultaneous ascent of respiration.

\subsection{Average annual fluxes}

As a way to ascertain general site differences in $\mathrm{CO}_{2}$ flux patterns, we used all available full months to construct average annual courses of NEE and its components GPP and TER. We calculated monthly sums of all fluxes (see Figs. B1, B2 and B3) and averaged these sums across all available records of each month. We summed up these monthly averages over 
Table 1. Annual net ecosystem exchange (NEE), total ecosystem respiration (TER) and gross primary production $(\mathrm{GPP}) \mathrm{CO}_{2}$ fluxes at both investigation sites for different 1-year time spans within the observed period between February 2016 and April 2018. Accumulated fluxes and uncertainties are expressed as carbon flux in grams per square meter per year $\left(\mathrm{g} \mathrm{m}^{-2} \mathrm{a}^{-1}\right)$. Random uncertainties of measured fluxes were estimated using the method of Finkelstein and Sims (2001), and modeled flux uncertainties were calculated by propagating individual random uncertainties through Eq. (1) (see Appendix A) (Jan: January; Feb: February; Mar: March; Apr: April).

\begin{tabular}{llrrr|rrr}
\hline & & \multicolumn{3}{c}{$2016-2017(\mathrm{Y} 1)$} & \multicolumn{3}{c}{ 2017-2018 (Y2) } \\
\cline { 3 - 7 } & & TER & GPP & NEE & TER & GPP & NEE \\
\hline \multirow{3}{*}{ Moat, cushion bog } & 1 Feb-31 Jan & $645 \pm 4$ & $-757 \pm 3$ & $-105 \pm 9$ & $644 \pm 4$ & $-764 \pm 3$ & $-103 \pm 12$ \\
& 1 Mar-28 Feb & $649 \pm 4$ & $-746 \pm 3$ & $-90 \pm 9$ & $651 \pm 4$ & $-786 \pm 3$ & $-115 \pm 12$ \\
& 1 Apr-31 Mar & $649 \pm 4$ & $-738 \pm 3$ & $-82 \pm 9$ & $661 \pm 4$ & $-810 \pm 3$ & $-129 \pm 12$ \\
\hline \multirow{2}{*}{ Pipo, raised bog } & 1 Mar-28 Feb & $392 \pm 3$ & $-399 \pm 2$ & $-9 \pm 7$ & $339 \pm 3$ & $-385 \pm 2$ & $-32 \pm 6$ \\
& 1 Apr-31 Mar & $389 \pm 3$ & $-397 \pm 2$ & $-8 \pm 7$ & $343 \pm 2$ & $-390 \pm 2$ & $-35 \pm 6$ \\
\hline
\end{tabular}

Table 2. Average change from the first to the second observed year of cumulated $\mathrm{CO}_{2}$ net ecosystem exchange NEE and its components' gross primary production GPP and total ecosystem respiration TER at both sites. Variations of environmental drivers between both years are represented by changes in the temperature sum growing degree days $\mathrm{GDD}_{5}$ and in cumulative photosynthetically active radiation $\mathrm{PAR}_{\text {cum. }}$. We used averages of the values given in Table 1 in detail to create this simplified overview. Increase or decrease by less than $5 \%(+/-)$, between $5 \%$ and $50 \%(++/--)$ and more than $50 \%(+++/---)$.

\begin{tabular}{|c|c|c|c|}
\hline & $\begin{array}{l}\text { 2016-2017 (Y1) } \\
\text { Moat, cushion bog }\end{array}$ & $\rightarrow$ & $\begin{array}{l}2017-2018(\mathrm{Y} 2) \\
\text { Pipo, raised bog }\end{array}$ \\
\hline $\mathrm{PAR}_{\text {cum }}$ & ++ & & + \\
\hline $\mathrm{GDD}_{5}$ & + & & -- \\
\hline$|\mathrm{GPP}|$ & ++ & & - \\
\hline TER & + & & -- \\
\hline$|\mathrm{NEE}|$ & ++ & & +++ \\
\hline
\end{tabular}

1 year from 1 September to 31 August to obtain mean annual courses as described in the methods section. Resulting annual sums, including the sums of the standard deviations of each mean month sum, are shown in Fig. 4. On average, the cushion bog takes up 4.5 times more $\mathrm{CO}_{2}$ than the mossdominated bog, resulting from twice as much photosynthetic uptake and only $80 \%$ higher respiratory $\mathrm{CO}_{2}$ loss. Moat develops its $\mathrm{CO}_{2}$ sink function much earlier in the year in midspring (October), whereas net $\mathrm{CO}_{2}$ uptake starts at Pipo only in summer (January). Cumulative $\mathrm{C}$ loss through respiration starts to level off in Pipo in late autumn, whereas respiration rates stay on more stable levels from mid-autumn throughout winter in Moat. Photosynthesis continues throughout winter at both sites with lowest rates occurring in June and July. At Moat, GPP starts to reach late autumn (May) rates again in August and the cumulative GPP curve slopes much steeper during spring and summer than at Pipo, where May GPP levels are reached again one month later in September.

\subsection{Flux-driver relations}

To characterize the two bogs' effectiveness in the use of total available PAR to fix $\mathrm{CO}_{2}$, we estimated a cumulative quantum yield $\phi_{\text {cum }}$ as the absolute slope of a linear regression between daily PAR and GPP sums. A quantum yield quantity in general is unitless as it describes the amount of fixed moles of $\mathrm{CO}_{2}$ per moles of absorbed photons per area and time. $\phi_{\text {cum }}$ describes this photon use efficiency on a daily cumulative basis. In contrast, the initial quantum yield $\alpha$ that is commonly used in plant-physiological studies, and also one of the parameters in our bulk model approach, describes the quantum use efficiency at initial light levels. Due to the nonlinear response of photosynthesis to PAR level, $\alpha$ values are about 1 order of magnitude larger than $\phi_{\text {cum }}$ values. The ratio between the cushion bog's and the raised bog's properties is similar with respect to both light use efficiency measures. The cushion plant-dominated communities in Moat are about twice as efficient in initial (see Fig. 2) and cumulative (see Fig. 5) photon use compared to the moss-dominated communities in Pipo. Based on the higher photon use efficiencies and the generally higher $P_{\max }$ levels at Moat, we hypothesized that cushion plants are able to still use additional radiation input effectively when moss photosynthesis is already at light saturation. To substantiate the assumption that cushion plant-dominated communities use additional photon input at high light levels more efficiently, we used Eq. (2) to

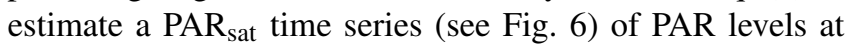
which photosynthesis was near light saturation (at $1 / 10$ of its initial quantum yield $\alpha$ ). During the vegetation periods, PAR $_{\text {sat }}$ values at Moat mostly exceeded those at Pipo and mostly also the amounts of incoming radiation (see Fig. 6), confirming our hypothesis. The moss-dominated communities appear to be progressively more adapted to using larger radiation input with PAR $_{\text {sat }}$ peaks late in summer. In contrast, the cushion plant-dominated community's ability to efficiently use high PAR input peaks in early summer, even earlier than radiation amounts reach their maximum, and drops off throughout the vegetation period. Winter GPP un- 

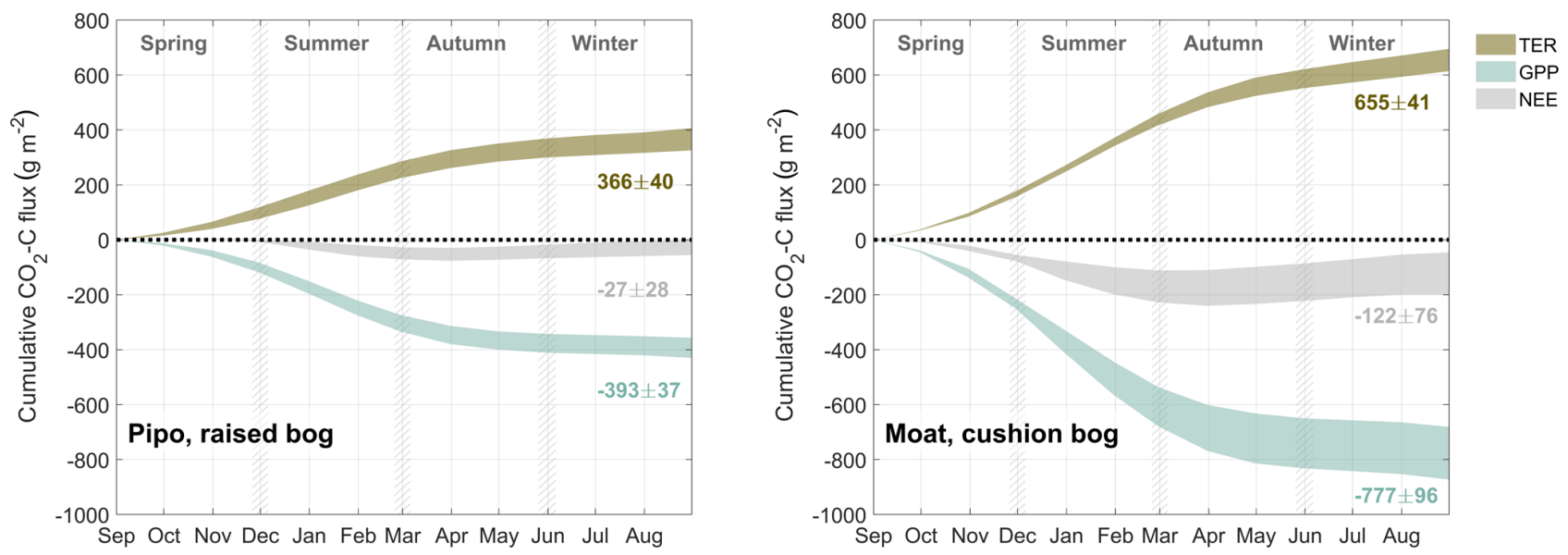

Figure 4. Comparison between average annual courses of cumulated $\mathrm{CO}_{2}$ net ecosystem exchange (NEE) flux and its components total ecosystem respiration TER and gross primary production GPP. Ranges denote the accumulated variability of month sums between the different observed years.

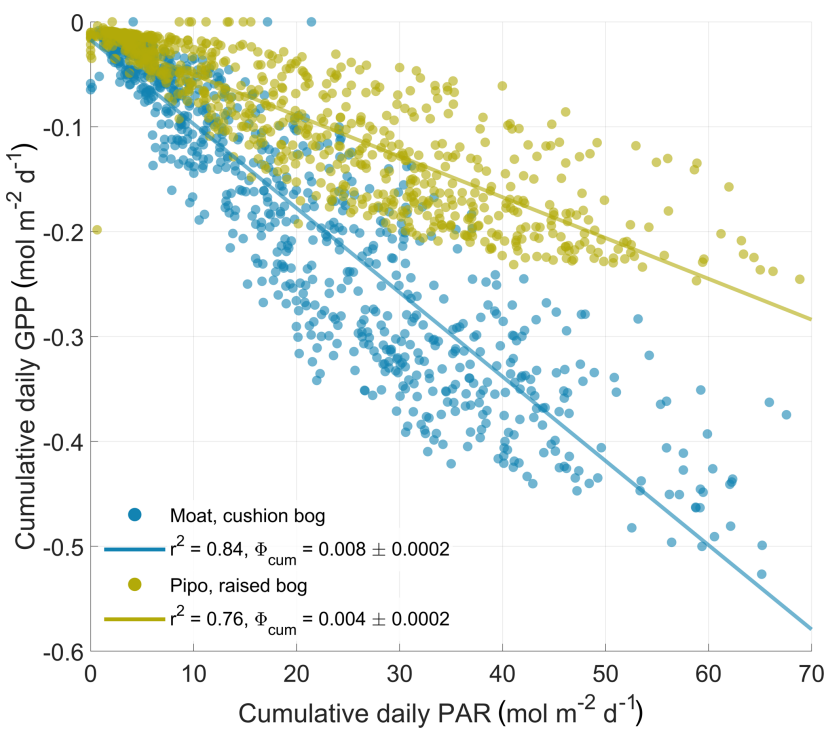

Figure 5. Response of daily gross primary production (GPP) sums to the sums of available photosynthetically active radiation (PAR) per day. The cumulative quantum yield $\phi_{\text {cum }}$ is defined as the absolute slope of a linear regression (ordinary least squares method) between both variables and denotes the average amount of fixed $\mathrm{CO}_{2}$ per amount of absorbed photons per area and time.

der lower cumulative light conditions stays at a higher level at Moat than at Pipo (see Fig. B1) due to the higher initial quantum yield of the cushion bog vegetation community (see Fig. 2). In contrast, during the normal (with mean temperatures close to the long-term average) winter of 2017, PAR $_{\text {sat }}$ at Pipo was higher than at Moat. Additionally, winter PAR sat $_{\text {. }}$ courses were more similar between 2016 and 2017 at Pipo.

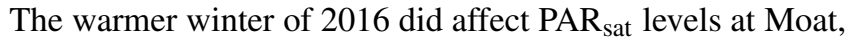
which exceeded those at Pipo during this cold season. The moss-dominated communities are therefore in principle able to use higher PAR levels in cool periods more effectively than the cushion plant-dominated communities. Taking into account the low amount of available radiation (see Fig. 6), the moss-dominated communities could, however, not profit from this beneficial trait as photosynthesis-saturating levels of PAR were never reached in any of the two observed winter periods. Photosynthesis limitation by temperature is more pronounced at Moat than at Pipo, but during a period of the year when radiation is the overriding limitation anyhow. Reasons for the highly effective PAR use of $A$. pumila have been investigated by Fritz (2012), who found up to 6 times more leaf nitrogen per area compared to $S$. magellanicum capitula. Furthermore, Fritz (2012) found a high density of chloroplasts in cross sections of $A$. pumila leaves sampled at the Moat cushion bog on Tierra del Fuego. This notion is substantiated by our own (unpublished) data of chlorophyll content per gram dry weight, which was elevated by factors of up to 10 in A. pumila leaves compared to S. magellanicum capitula. As a key competitive strategy of cushion plants for efficient nutrient recycling (Fritz, 2012) is the development of a dense and large root system, which contributes up to $90 \%$ to their total biomass, the respiration cost that the plant imposes on itself by the maintenance of a large belowground part is high. The comparably high ecosystem respiration fluxes we determined in this study also point in this direction.

We investigated the effect of prolonged warm periods on ecosystem respiration by inspecting possible functional relationships between GDD $_{5}$ and monthly TER sums. Taking into account the higher number of parameters by calculating the corrected Akaike information criterion AICc, secondorder polynomial fits yielded the best model performances (see Fig. 7). These function shapes suggest a $\mathrm{GDD}_{5}$ optimum for TER and a limitation of TER during the warmest months. The parabola vertex and thereby the $\mathrm{GDD}_{5}$ optimum 


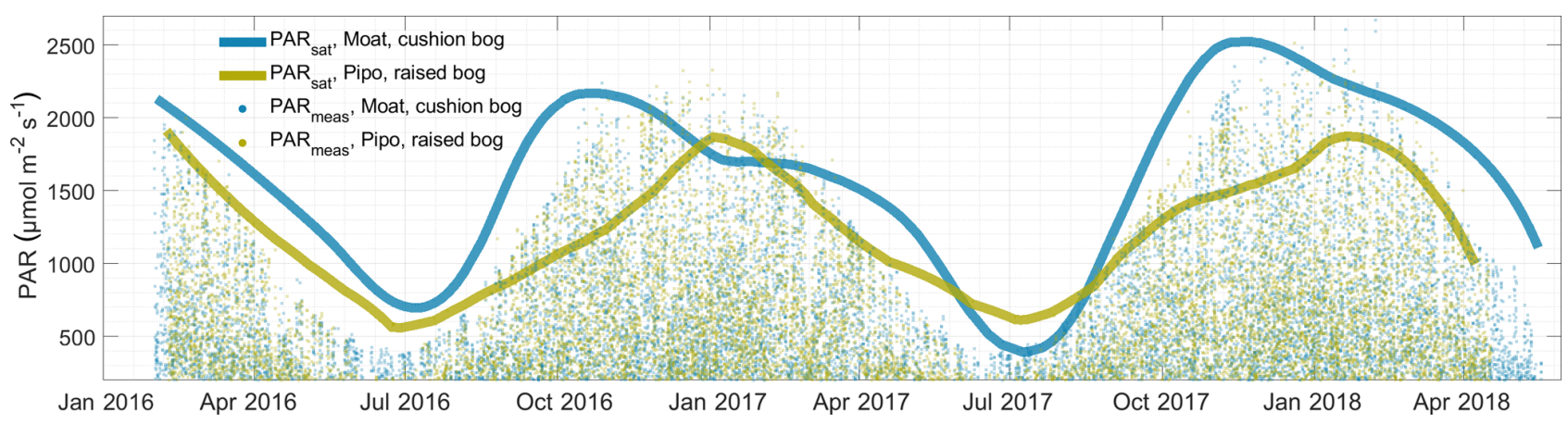

Figure 6. Modeled $\mathrm{PAR}_{\mathrm{sat}}$ time series indicating the value at which photon use efficiency reaches $1 / 10$ of the initial quantum use efficiency for the cushion plant-dominated site at Moat and the moss-dominated site at Pipo. Half-hourly measured PAR time series are also shown (PAR meas).

was surpassed during the warmest months at Pipo, whereas it lies just outside the observed GDD5 range at Moat. Overall, TER in Moat is at a higher level also during cold periods $\left(\mathrm{GDD}_{5}=0\right)$ and increases more strongly with additional heat input than in Pipo.

\subsection{Comparison with other bog ecosystems}

We compared the NEE balances of this study to results from similar ecosystems. In case of the Pipo data set, we used long-term NEE observations from a Northern Hemisphere ombrotrophic raised bog in Canada and mean Holocene peat accumulation rates inferred from peat cores of other Patagonian bogs. We chose the Canadian Mer Bleue peatland as a reference because it represents a typical Sphagnumdominated Northern Hemisphere bog and complete, multiannual eddy covariance NEE, GPP and TER data have been published from this site. The average characteristics of Northern Hemisphere ombrotrophic bogs are well documented in these data sets and therefore enable a fairly robust estimation of differences with our $\mathrm{CO}_{2}$ flux observations from a Southern Hemisphere Sphagnum-dominated raised bog. To evaluate if the results presented in this study can be seen as representative of Patagonian raised bogs in general or constitute an outlier because $\mathrm{CO}_{2}$ flux dynamics are rather driven by local than by regional conditions, we used peat core data that have been acquired in similar bogs across southern Patagonia. For this comparison we took into account further components of the $\mathrm{C}$ balance as NEE can not directly be compared with peat accumulation rates. In the case of our cushion bog data from Moat, comparisons with other global wetland types are less straight forward. Cushion bogs only exist on the Southern Hemisphere and have not been studied before in terms of their $\mathrm{CO}_{2}$ flux dynamics. Similarities with other bog ecosystems from where NEE data have been published exist with respect to isolated features like the general geomorphological setting or the fact that they are located on the Southern Hemisphere and are vascular-plant dominated. For comparison, we used literature data from (I) Atlantic blanket bogs in Ireland that share their close proximity to the sea and the uneven subsurface relief they grow on with Patagonian cushion bogs and (II) NEE observations from Kopuatai bog in New Zealand, which is also located on the Southern Hemisphere and is likewise dominated by vascular plants. Distinctions between these bogs and Patagonian cushion bogs are, however, pronounced. Even though the Kopuatai bog in New Zealand is also vascular plant dominated, the most abundant plant is a rush with a much higher growth height and distinctively lower root biomass than the cushionforming plants Astelia pumila and Donatia fascicularis. Furthermore, Kopuatai bog is nearly $20^{\circ}$ closer to the Equator, decisively modulating the received radiation input in comparison to the cushion bog at Moat. Atlantic blanket bogs share the oceanic climate component and relief features of the underlying geology with the Fuegian cushion bog investigated in this study. Distinctions arise with respect to plant communities, as, again, the occurring vascular plants do differ and a large belowground root biomass can not be found in blanket bogs. Moreover, bryophyte cover is distinctly higher (Sottocornola et al., 2009) than in the cushion bog at Moat.

To represent $\mathrm{CO}_{2}$ flux dynamics of a typical raised Sphagnum bog we inspected results from the moss-dominated ombrotrophic raised bog Mer Bleue in Ontario, Canada, from where extensive flux time series exist. Roulet et al. (2007) estimated cumulative NEE-C fluxes based on multi-annual EC time series from the moss-dominated Mer Bleue bog to average at $-40.2 \pm 40.5 \mathrm{~g} \mathrm{~m}^{-2} \mathrm{a}^{-1}$. The mean net $\mathrm{CO}_{2}$ uptake of the raised bog at Pipo is within the same order of magnitude but comparably low. Similar to what we found in this study at the $S$. magellanicum-dominated site, inter-annual variability at Mer Bleue is high $\left(-2\right.$ to $\left.-112 \mathrm{~g} \mathrm{~m}^{-2} \mathrm{a}^{-1}\right)$. Large interannual variability and even switches from NEE-C source to sink, as also indicated in our study, are also known from other global peatlands (Arneth et al., 2002; Aurela et al., 2002). Average NEE component sums from Pipo are both of lower magnitude than reported by Moore et al. (2002) from Mer Bleue, where $|\mathrm{GPP}|$ is about $25 \%$ larger, and TER is about $30 \%$ larger. Reasons for this lower productivity at the 

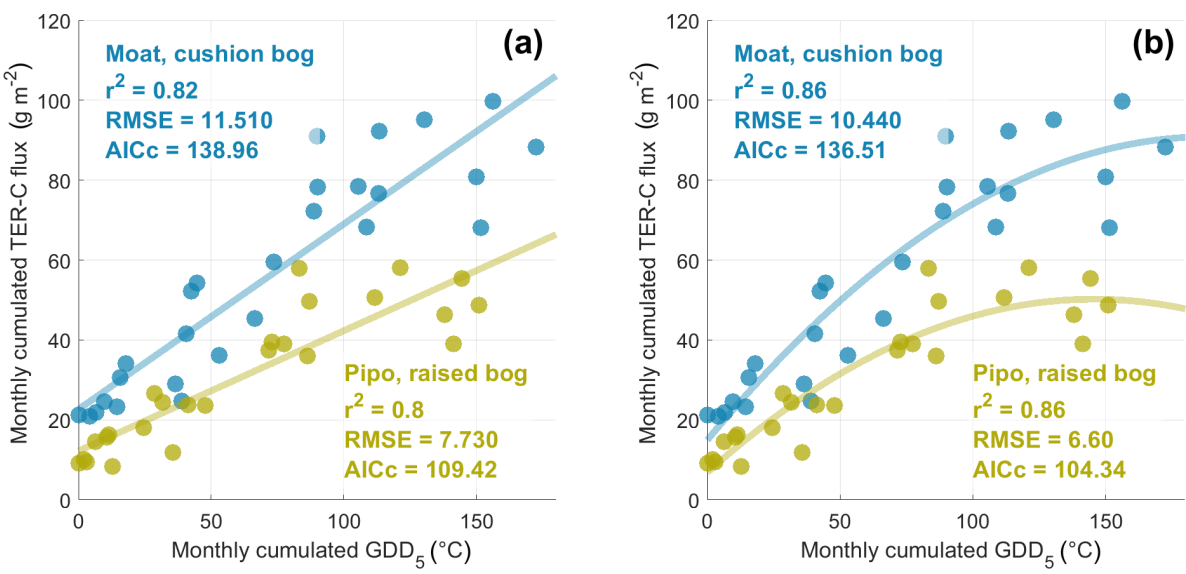

Figure 7. A linear (a) and a second-order polynomial (b) fit between monthly cumulated growing degree days (GDD) and monthly total ecosystem respiration (TER) sums. While the coefficient of determination $\left(r^{2}\right)$ is higher for the parabolic fit, corrected Akaike information criterion (AICc) values and root mean square errors (RMSEs) are lower than for the linear fit at both sites. Better model performances of second-order polynomial fits suggest a GDD 5 optimum of TER at both sites.

Fuegian raised bog in our study might be diverse. In terms of vegetation composition, a peculiarity of Fuegian mossdominated bogs is the fact that only one Sphagnum species forms the different microforms (hummocks and lawns) that occur in these patterned bogs. S. magellanicum is, however, most likely not as well adapted to all these topographic positions, which possibly diminishes the overall productivity of these bogs in comparison to more diverse northern mires. A further reason for the higher $\mathrm{CO}_{2}$ uptake rates at Mer Bleue could be climatic distinctions. While the mean annual air temperature at Mer Bleue $\left(6^{\circ} \mathrm{C}\right)$ is similar to our 2017 value $\left(5.3^{\circ} \mathrm{C}\right)$ and to the long-term average for Ushuaia $\left(5.5^{\circ} \mathrm{C}\right)$, mean annual precipitation at Mer Bleue is with $943 \mathrm{~mm}$ nearly twice as high compared to what we measured between 1 March 2016 and 28 February $2017(515 \mathrm{~mm})$ at the Pipo raised bog. Additionally, evapotranspiration was nearly $200 \mathrm{~mm}$ higher during the same period, making our first observed year very dry, which consequently imposed severe water stress on the vegetation. As already noted by Lehmann et al. (2016) in 2015, we additionally observed a considerable, and in 2016 increasing, amount (between around 5\% and $10 \%$ ) of surface being covered by lichens. Harris et al. (2018) showed that the presence of lichens indicate conditions that support near-zero $\mathrm{C}$ accumulation rates by limiting Sphagnum growth. Finally, our investigation of different photon use efficiency measures of the moss-dominated plant communities at Pipo indicates a non-optimal adaption of plant traits to the local conditions. While the vegetation at Pipo could use higher photon fluxes in winter than are actually present, the plant community is not able to efficiently use actually occurring high radiation input in summer (see Fig. 6).

With respect to long-term $\mathrm{C}$ sequestration, Loisel et al. (2014) reported average Holocene rates of $22.9 \pm$ $2.0 \mathrm{~g} \mathrm{~m}^{-2} \mathrm{a}^{-1}$ for Northern Hemisphere ombrotrophic and minerotrophic peatlands. In a meta-analysis of peat core data from mostly peat moss-dominated bogs in Patagonia, Loisel and $\mathrm{Yu}$ (2013) found average Holocene C accumulation rates of $16 \mathrm{~g} \mathrm{~m}^{-2} \mathrm{a}^{-1}$, indicating a reduced $\mathrm{C}$ uptake rate of Patagonian bogs compared to average Northern Hemisphere peatlands. NEE can not be compared directly to longterm $\mathrm{C}$ uptake rates as the $\mathrm{C}$ balance is comprised of further flux components like lateral transport of dissolved organic carbon (DOC) or vertical $\mathrm{CH}_{4}-\mathrm{C}$ flux. Methane flux data are available for both sites in this study from Lehmann et al. (2016) and Münchberger et al. (2019). Taking into account the different surface cover of various vegetation communities, Lehmann et al. (2016) report a mean daily, areaweighted $\mathrm{CH}_{4}$ flux of $13.1 \pm 7.4 \mathrm{mg} \mathrm{m}^{-2} \mathrm{~d}^{-1}$ referring to the whole bog area on a summer day at Pipo. Cumulating this daily flux over 1 year yields an evidently overestimated annual $\mathrm{CH}_{4}-\mathrm{C}$ flux of $3.59 \pm 2.03 \mathrm{~g} \mathrm{~m}^{-2} \mathrm{a}^{-1}$, which is, however, still lower than the average $\mathrm{CH}_{4}-\mathrm{C}$ flux of $3.7 \mathrm{~g} \mathrm{~m}^{-2} \mathrm{a}^{-1}$ measured by Roulet et al. (2007) at Mer Bleue. It stands to reason that the lower plant productivity we observed at the Fuegian Sphagnum bog is correlated with lower $\mathrm{CH}_{4}$ emissions compared to Mer Bleue. Putting our result of an average annual NEE of $-27 \pm 28 \mathrm{~g} \mathrm{~m}^{-2} \mathrm{a}^{-1}$ into context with the long-term $\mathrm{C}$ accumulation of $16 \mathrm{~g} \mathrm{~m}^{-2} \mathrm{a}^{-1}$ that Loisel and $\mathrm{Yu}$ (2013) determined for Patagonian bogs, also requires an approximation of lateral DOC transport. For Northern Hemisphere raised bogs, DOC loss has been estimated to be around $10 \mathrm{~g} \mathrm{~m}^{-2} \mathrm{a}^{-1}$ (Roulet et al., 2007; Moore et al., 2002). Taking into account this rough approximation of DOC flux and the comparably small $\mathrm{CH}_{4}-\mathrm{C}$ fluxes at Pipo (Lehmann et al., 2016), the NEE-C balance we determined in this study appears conceivable when compared to long-term Holocene $\mathrm{C}$ accumulation rates from Loisel and $\mathrm{Yu}$ (2013).

Annual C flux data from other vascular plant-dominated Southern Hemisphere bogs have so far been published 
by Campbell et al. (2014) and Goodrich et al. (2015a, b) from Kopuatai bog on the north island of New Zealand $\left(37^{\circ} 55.5^{\prime} \mathrm{S}\right)$, which is dominated by the wire rush Empodisma robustum and other species from the family Restionaceae with sporadic appearance of Sphagnum mosses. Two years of $\mathrm{EC} \mathrm{CO}_{2}$ fluxes reported by Campbell et al. (2014) show NEE-C sums between -250.3 and $-218.2 \mathrm{~g} \mathrm{~m}^{-2} \mathrm{a}^{-1}$. Net $\mathrm{CO}_{2}-\mathrm{C}$ uptake of these New Zealand bogs was therefore about twice as large as at the Fuegian cushion bog investigated for the present study while also cumulative $|\mathrm{GPP}|$ and TER fluxes are both about $30 \%$ larger. In contrast to the Fuegian cushion bog, seasonal variability of the photosynthetic potential at the Empodisma robustum-dominated bog in New Zealand is small (Goodrich et al., 2015a). Methane $C$ loss at the latter site was with up to $21.75 \mathrm{~g} \mathrm{~m}^{-2} \mathrm{a}^{-1}$ (Goodrich et al., 2015b) considerably larger than at the studied Fuegian cushion bog, where soilatmosphere $\mathrm{CH}_{4}$ exchange is very low (Fritz et al., 2011; Münchberger et al., 2019).

The intense transport of oxygen through the dense root system of A. pumila results in low $\mathrm{CH}_{4}$ fluxes. Cumulating mean daily summer fluxes measured by Münchberger et al. (2019) at Moat yields, once again, a most likely overestimated annual $\mathrm{CH}_{4}-\mathrm{C}$ flux of $0.39 \pm 0.70 \mathrm{~g} \mathrm{~m}^{-2} \mathrm{a}^{-1}$ for cushions dominated by A. pumila and an even lower flux sum of $0.23 \pm 0.25 \mathrm{~g} \mathrm{~m}^{-2} \mathrm{a}^{-1}$ from the pools between cushions. On the other hand, $\mathrm{CH}_{4}-\mathrm{C}$ fluxes from the seldom S. magellanicum patches at Moat are with $6.66 \pm 4.82 \mathrm{~g} \mathrm{~m}^{-2} \mathrm{a}^{-1}$ larger than at Pipo.

Atlantic blanket bogs that develop in similar relief settings but receive more than 3 times more precipitation (Laine et al., 2006) compared to Fuegian cushion bogs show generally lower annual NEE-C uptake rates as reported by Sottocornola and Kiely $(2005,2010)$ and Koehler et al. (2011) from a blanket bog in Ireland $\left(51^{\circ} 55^{\prime} \mathrm{N}\right)$. Based on 6 years of EC data, the latter authors estimated mean annual NEE$\mathrm{C}$ fluxes of $-47.8 \pm 30.0 \mathrm{~g} \mathrm{~m}^{-2} \mathrm{a}^{-1}$, about half of the netuptake rate at Moat. Coastal blanket bogs at higher latitudes exhibit a smaller net $\mathrm{CO}_{2}$ sink strength as estimated by Lund et al. (2015) at a boreal blanket bog in Norway $\left(68^{\circ} 08^{\prime} \mathrm{N}\right)$. There, mean annual NEE-C fluxes based on 5 years of EC measurements amounted to $-19.5 \pm 18.3 \mathrm{~g} \mathrm{~m}^{-2} \mathrm{a}^{-1}$. With $4.1 \pm 0.5 \mathrm{~g} \mathrm{~m}^{-2} \mathrm{a}^{-1}$ (Koehler et al., 2011) $\mathrm{CH}_{4}$-C flux, blanket bog $\mathrm{CH}_{4}$ emissions are comparable to what has been determined for Northern Hemisphere raised bogs and much higher than in Moat (Münchberger et al., 2019).

\section{Conclusions}

The two investigated Fuegian bog ecosystems are located in relatively close proximity to each other but at contrasting topographic positions. The moss-dominated raised bog developed in a depressed glaciogenic valley bottom, whereas the cushion bog established directly at the coast of the Beagle
Channel close to a terminal moraine position of the last ice age and covers more uneven, sloped terrain. The proximity of the cushion bog to the sea especially leads to deviations in the local weather conditions between the cushion bog and the moss-dominated bog in the valley. Contrasting vegetation communities developed at the sites: the raised bog is dominated by the peat moss $S$. magellanicum and the cushion bog by the vascular plant $A$. pumila, which is characterized by a dense root system.

Both bogs show distinct surface-atmosphere $\mathrm{CO}_{2}$ flux dynamics. Average annual net $\mathrm{CO}_{2}-\mathrm{C}$ uptake at the cushion bog is with a factor of 4.5 clearly larger than at the raised $S$. magellanicum bog. Site differences arise with respect to $\mathrm{CO}_{2}$ net exchange and relating to photosynthetic uptake as well as to ecosystem respiration. Both of the latter NEE components are of larger magnitude at the cushion bog: TER is $80 \%$ larger, and |GPP| is twice as large. Relative inter-annual variability is higher at the raised bog but substantial at both sites. The raised bog responded to the comparably warm and dry first year of the 2 years observed with a large relative increase in TER and a smaller rise of GPP. Although more cumulative radiation was available in the cooler second year, GPP did not increase at the raised bog. In contrast to the conditions at the raised bog, cumulative temperature expressed as GDD was very similar in both years at the cushion bog. Close to the sea, the summer of the first year was particularly cloudy, and photosynthetic $\mathrm{CO}_{2}$ uptake increased substantially in the second year under conditions of higher cumulative PAR availability.

In summary, the raised bog's NEE balance is within the typical range of data from similar moss-dominated Northern Hemisphere raised bogs, while it belongs to the less productive varieties. Compared to global moss-dominated bogs, the investigated Fuegian cushion bog exhibits a much larger net $\mathrm{CO}_{2}$ uptake. Closer to the Equator on the Southern Hemisphere, vascular plant-dominated bogs exist in New Zealand that, while emitting more $\mathrm{CH}_{4}$, take up even more net $\mathrm{CO}_{2}$ per year. The cushion bog in this study generally took up about a factor of 2 more net $\mathrm{CO}_{2}-\mathrm{C}$ per year than Atlantic blanket bogs that occur in similar geomorphological settings on the Northern Hemisphere. Although cushion bog ecosystems are exclusive to the Southern Hemisphere, they are an integral part of one of the largest global wetland complexes (Fraser and Keddy, 2005), the Magellanic Moorland. It extends outside of Tierra del Fuego to the north along the Pacific coast of Chile and covers an area of $44000 \mathrm{~km}^{2}$ (Arroyo et al., 2005). Future regional-scale estimates of landatmosphere $\mathrm{CO}_{2}$ exchange fluxes from the Magellanic Moorland should take into account the apparently higher primary production and higher ecosystem respiration of cushion bogs compared to raised bogs that both form this large wetland complex. The higher productivity of cushion plants could also be part of an explanation for the apparent competitive advantage cushion plants had over peat mosses when they invaded Fuegian Sphagnum peatlands during a shift of climatic conditions in the region around 2600 years BP. 
Data availability. Data are available for download on the AmeriFlux website (https://ameriflux.lbl.gov/sites/siteinfo/ AR-TF1, last access: 2 August 2019, Kutzbach, 2019a, https://ameriflux.lbl.gov/sites/siteinfo/AR-TF2, last access:

2 August 2019, Kutzbach, 2019b). 
Appendix A: Bulk model error propagation

$$
\begin{aligned}
u_{\mathrm{GPP}} & =2 \times \sqrt{\left(\frac{\delta \mathrm{GPP}}{\delta P_{\max }}\right)^{2} \times u_{P_{\max }}^{2}+\left(\frac{\delta \mathrm{GPP}}{\delta \alpha}\right)^{2} \times u_{\alpha}^{2}} \\
& =2 \times \sqrt{\left(\frac{\alpha^{2} \mathrm{PAR}^{2}}{\left(P_{\max }+\alpha \mathrm{PAR}\right)^{2}}\right)^{2} \times u_{P_{\max }}^{2}+\left(\frac{P_{\max }^{2} \mathrm{PAR}}{\left(P_{\max }+\alpha \mathrm{PAR}\right)^{2}}\right)^{2} \times u_{\alpha}^{2}} \\
u_{\mathrm{TER}} & =2 \times \sqrt{\left(\frac{\delta \mathrm{TER}}{\delta R_{\text {base }}}\right)^{2} \times u_{R_{\text {base }}}^{2}+\left(\frac{\delta \mathrm{TER}}{\delta Q_{10}}\right)^{2} \times u_{Q_{10}}^{2}} \\
& =2 \times \sqrt{\left(Q_{10}^{\frac{T-15}{10}}\right)^{2} \times u_{R_{\text {base }}}^{2}+\left(R_{\text {base }} \times \frac{T-15}{10} \times Q_{10}^{\frac{T-15}{10}-1}\right)^{2} \times u_{Q_{10}}^{2}} \\
u_{\mathrm{NEE}} & =2 \times \sqrt{u_{\mathrm{GPP}}^{2}+u_{\mathrm{TER}}^{2}}
\end{aligned}
$$




\section{Appendix B: Cumulative bulk model results}
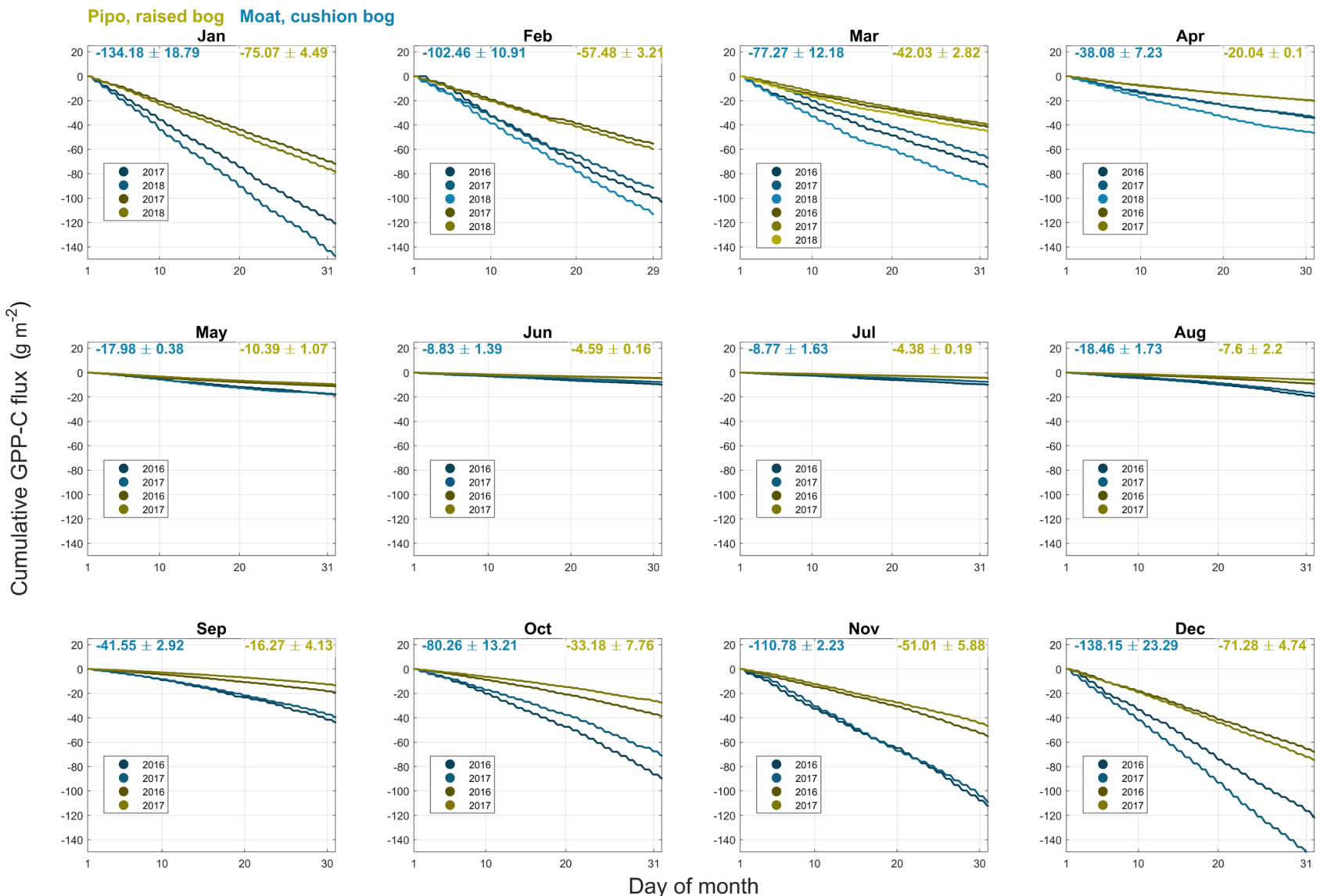

Figure B1. Cumulative gross primary production (GPP) $\mathrm{CO}_{2}$ fluxes including standard deviations for monthly intervals of all available full months within the years 2016, 2017 and 2018 at both investigation sites (yellow: Pipo, moss-dominated bog; blue: Moat, cushion plantdominated bog). 
Pipo, raised bog Moat, cushion bog
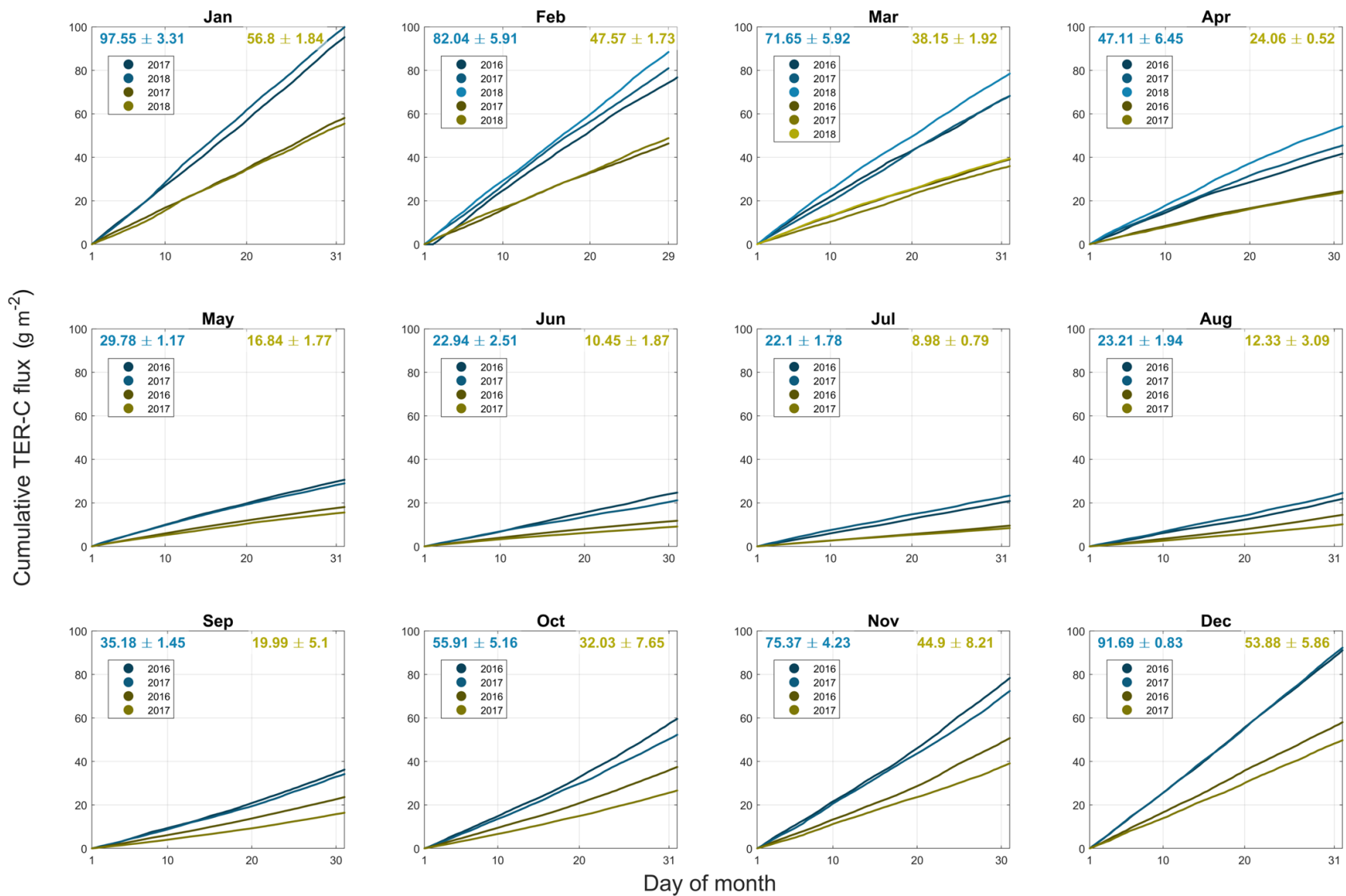

Figure B2. Cumulative total ecosystem respiration (TER) $\mathrm{CO}_{2}$ fluxes including standard deviations for monthly intervals of all available full months within the years 2016, 2017 and 2018 at both investigation sites (yellow: Pipo, moss-dominated bog; blue: Moat, cushion plantdominated bog). 
Pipo, raised bog Moat, cushion bog
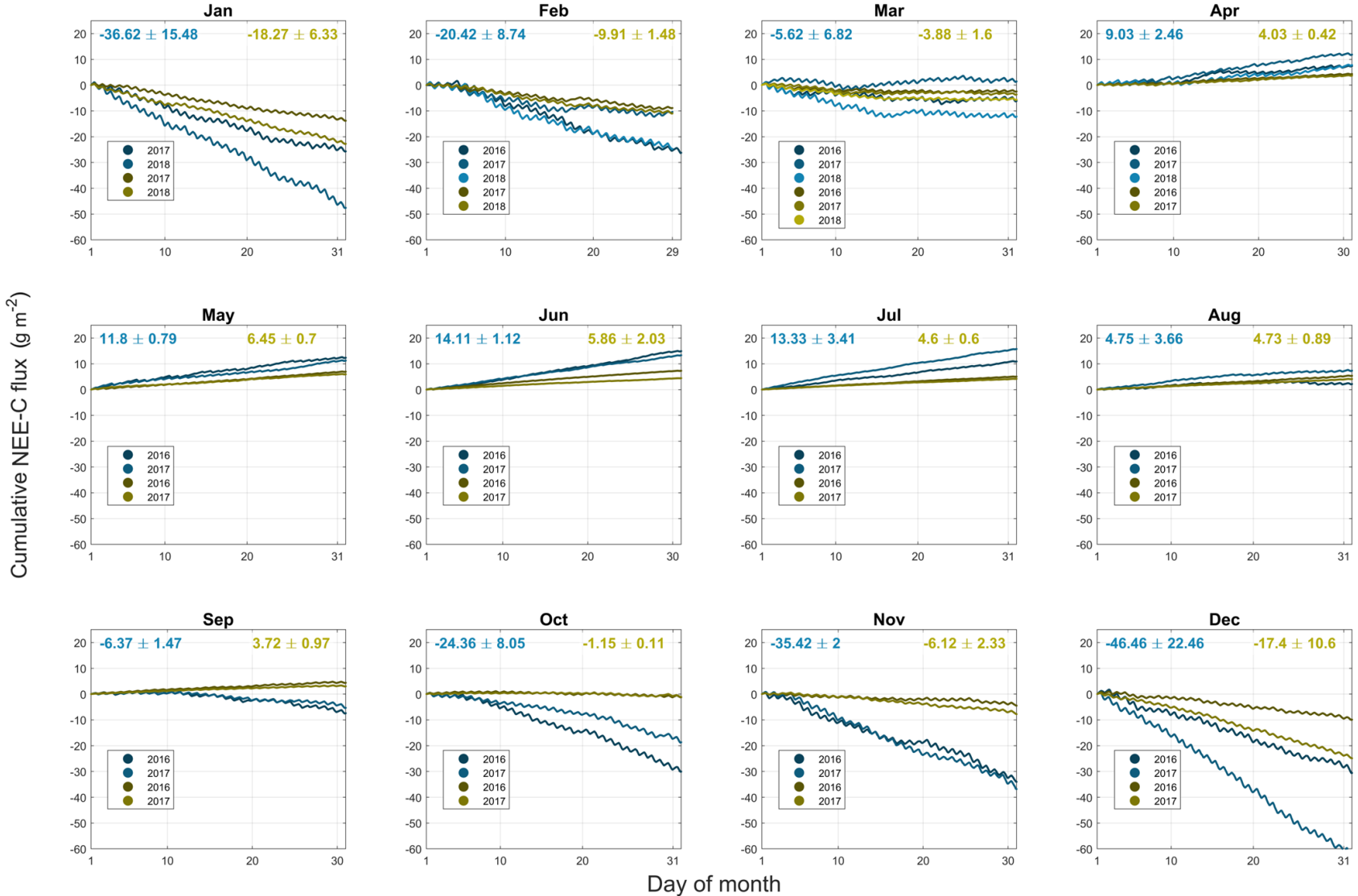

Figure B3. Cumulative net ecosystem exchange (NEE) $\mathrm{CO}_{2}$ fluxes including standard deviations for monthly intervals of all available full months within the years 2016, 2017 and 2018 at both investigation sites (yellow: Pipo, moss-dominated bog; blue: Moat, cushion plantdominated bog). 
Appendix C: Cumulative temperature and radiation measures

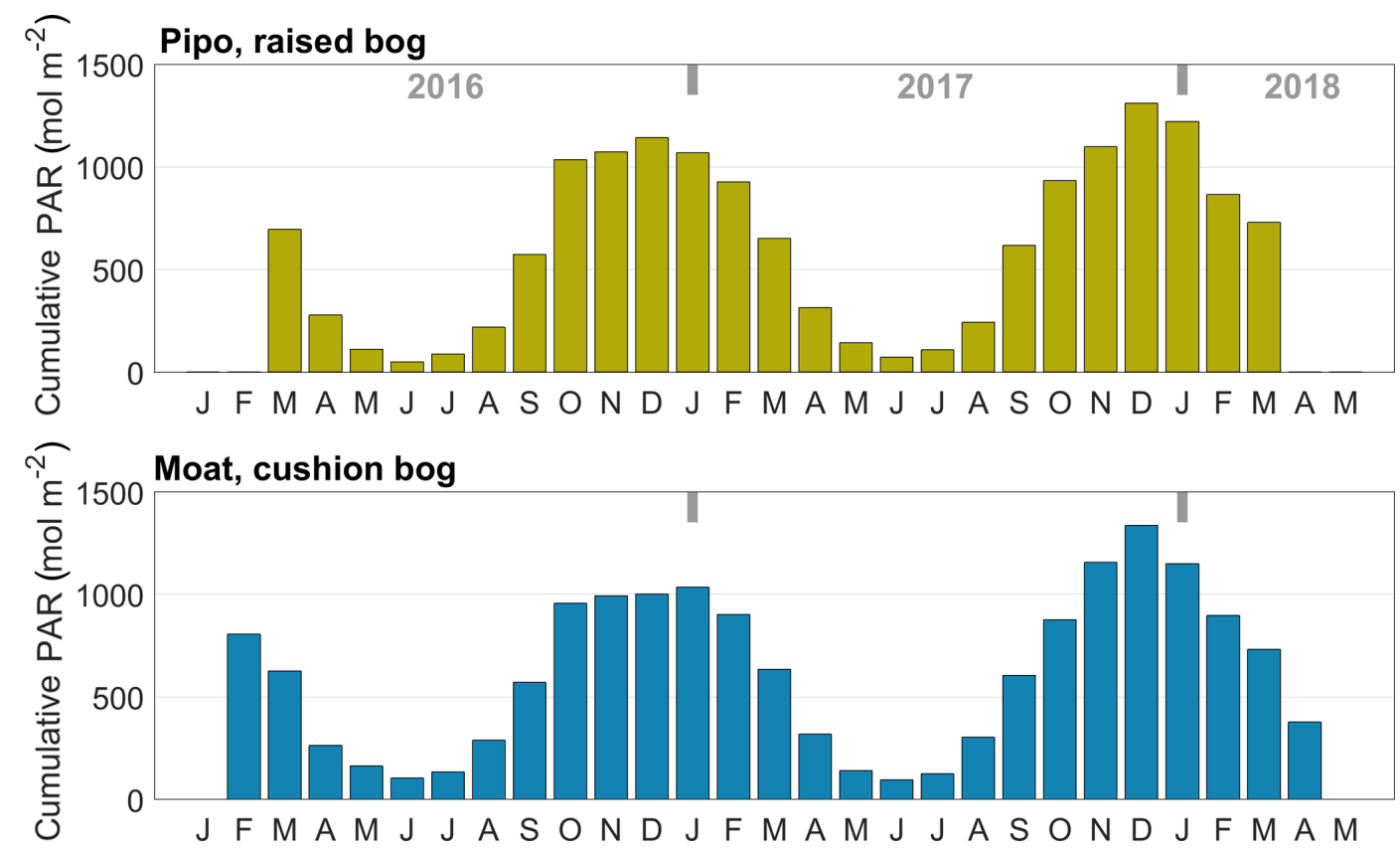

Figure C1. Monthly cumulated photosynthetically active radiation (PAR) at the two investigation sites.
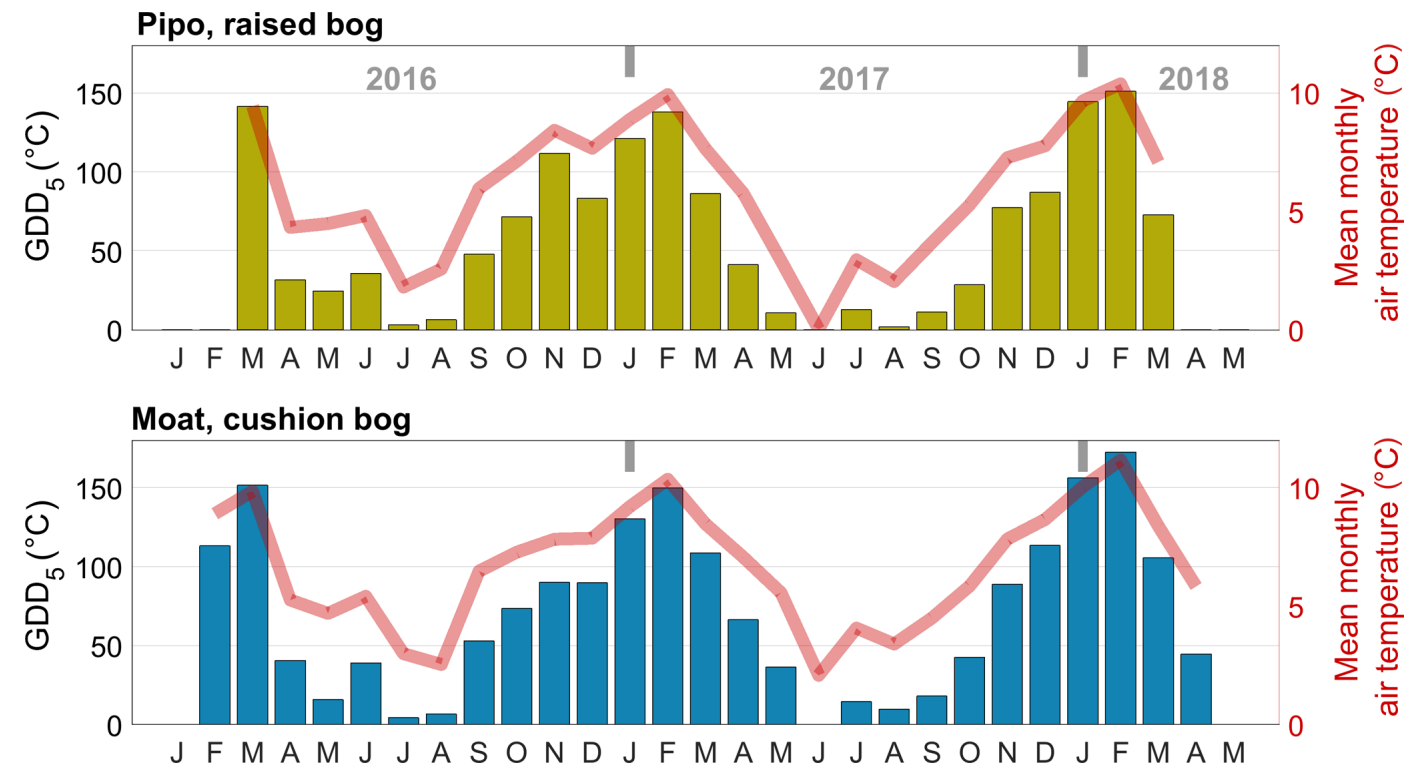

Figure C2. Monthly growing degree days (GDD) and mean air temperature at the two investigation sites. 


\section{Appendix D: PAR $_{\text {sat }}$ calculation}

PAR $_{\text {sat }}$ denotes the radiation value at which the quantum use efficiency is reduced to $1 / 10$ of the initial quantum yield $\alpha$. We calculated the slope of GPP(PAR) (see Eq. 1) as follows:

$\mathrm{GPP}^{\prime}(\mathrm{PAR})=\frac{P_{\max }^{2} \alpha}{\left(P_{\max }+\alpha \mathrm{PAR}\right)^{2}}$

and used an attenuation factor $z_{\text {sat }}$ of 10 to scale $\alpha$ to an attenuated quantum use efficiency $\left(\frac{\alpha}{z_{\text {sat }}}\right)$ that we set equal to $\operatorname{GPP}^{\prime}\left(\mathrm{PAR}_{\text {sat }}\right)$, yielding

$\frac{\alpha}{z_{\mathrm{sat}}}=\frac{P_{\max }^{2} \alpha}{\left(P_{\max }+\alpha \mathrm{PAR}_{\mathrm{sat}}\right)^{2}}$,

which can be rewritten as the following:

$\mathrm{PAR}_{\text {sat }}^{2}+\frac{2 P_{\text {max }}}{\alpha}$ PAR $_{\text {sat }}+P_{\text {max }}\left(\frac{1}{z_{\text {sat }}-1}\right)=0$.

The positive solution of Eq. (D3) is given as Eq. (2) and was used to calculate PAR $_{\text {sat }}$. 
Author contributions. LK and VP conceptualized and administered the planning of the research activity and acquired the funds for it. AH, DH, LK, VP and SJC conducted the field work. SJC contributed data. $\mathrm{AH}$ and $\mathrm{DH}$ conducted literature research. DH analyzed the data, created visualizations and wrote the original draft. $\mathrm{AH}, \mathrm{DH}, \mathrm{LK}, \mathrm{VP}$ and SJC reviewed and edited the original draft.

Competing interests. The authors declare that they have no conflict of interest.

Acknowledgements. During field work, we were kindly hosted at and supported by staff and facilities of Centro Austral de Investigaciones Científicas (CADIC) operated by Consejo Nacional de Investigaciones Científicas y Técnicas (CONICET) in Ushuaia. We are especially grateful for the kind support of all members of the Laboratorio de Ecología Terrestre at CADIC. We very much appreciate being able to work in Parque Nacional Tierra del Fuego and want to thank APN (Administración de Parques Nacionales, Argentina). The Prefectura Naval Argentina kindly granted permission to set up one of our wind turbines on their property, and their officers at the guard post in Moat always welcomed us with most amicable hospitality. For supporting our fieldwork, we want to express our gratitude to Julio M. Escobar, Rodolfo Iturraspe, Ramiro Lopez, Christian Blodau, Till Kleinebecker, Wiebke Münchberger, Norman Rüggen, Tom Huber, Carla Bockermann, Isabella Närdemann, Juliane Kohlstruck, Laura Jansen, María Florencia Castagnani and María Noel Szudruk Pascual. We thank Gastón Kreps for sharing data from the meteorological long-term observations at CADIC. For his comprehensive support during the technical planning of the measurement campaigns we thank Christian Wille.

Financial support. This work was supported by the Cluster of Excellence CliSAP (EXC177), Universität Hamburg, funded by the German Research Foundation (DFG) and by the DFG project KU 1418/6-1.

Review statement. This paper was edited by Ivonne Trebs and reviewed by Nigel Roulet and one anonymous referee.

\section{References}

Arneth, A., Kurbatova, J., Kolle, O., Shibistova, O. B., Lloyd, J., Vygodskaya, N. N., and Schulze, E.-D.: Comparative ecosystem-atmosphere exchange of energy and mass in a European Russian and a central Siberian bog II. Interseasonal and interannual variability of $\mathrm{CO}_{2}$ fluxes, Tellus B, 54, 514-530, 2002.

Arroyo, M., Pliscoff, P., Mihoc, M., and Arroyo-Kalin, M.: The Magellanic moorland, in: The World's Largest Wetlands: Ecology and Conservation, edited by: Fraser, L. and Keddy, P., Cambridge University Press, Cambridge, 2005.

Aubinet, M., Vesala, T., and Papale, D.: Eddy covariance: a practical guide to measurement and data analysis, Springer Science \& Business Media, Dordrecht, 2012.
Auer, V.: The Pleistocene of Fuego-Patagonia. Part IV: Bog Profiles, no. 1-3 in Annales Academiae Scientiarum Fennicae: Geologica-geographica, Suomalainen Tiedeakatemia, Helsinki, 1965.

Aurela, M., Laurila, T., and Tuovinen, J.-P.: Annual $\mathrm{CO}_{2}$ balance of a subarctic fen in northern Europe: importance of the wintertime efflux, J. Geophys. Res.-Atmos., 107, D21, https://doi.org/10.1029/2002JD002055, 2002.

Björck, S., Rundgren, M., Ljung, K., Unkel, I., and Åsa Wallin: Multi-proxy analyses of a peat bog on Isla de los Estados, easternmost Tierra del Fuego: a unique record of the variable Southern Hemisphere Westerlies since the last deglaciation, Quaternary Sci. Rev., 42, 1-14, 2012.

Blanco, D. E. and de la Balze, V. M.: Los Turbales de la Patagonia. Bases para su inventario y la conservaciòn de su biodiversidad, Wetlands International, Buenos Aires, 2004.

Borromei, A. M., Ponce, J. F., Coronato, A., Candel, M. S., Olivera, D., and Okuda, M.: Reconstrucción de la vegetación posglacial y su relación con el ascenso relativo del nivel del mar en el extremo este del canal Beagle, Tierra del Fuego, Argentina, Andean Geology, 41, 362-379, 2014.

Burba, G., Schmidt, A., Scott, R. L., Nakai, T., Kathilankal, J., Fratini, G., Hanson, C., Law, B., McDermitt, D. K., Eckles, R., Furtaw, M., and Velgersdyk, M.: Calculating $\mathrm{CO}_{2}$ and $\mathrm{H}_{2} \mathrm{O}$ eddy covariance fluxes from an enclosed gas analyzer using an instantaneous mixing ratio, Global Change Biol., 18, 385-399, 2012.

Campbell, D. I., Smith, J., Goodrich, J. P., Wall, A. M., and Schipper, L. A.: Year-round growing conditions explains large $\mathrm{CO} 2$ sink strength in a New Zealand raised peat bog, Agric. Forest Meteorol., 192, 59-68, 2014.

Cleveland, W. S.: Robust locally weighted regression and smoothing scatterplots, J. Am. Stat. Assoc., 74, 829-836, 1979.

Falge, E., Baldocchi, D., Olson, R., Anthoni, P., Aubinet, M., Bernhofer, C., Burba, G., Ceulemans, R., Clement, R., Dolman, H., Granier, A., Gross, P., Grünwald, T., Hollinger, D., Jensen, N.O., Katul, G., Keronen, P., Kowalski, A., Ta Lai, C., Law, B. E., Meyers, T., Moncrieff, J., Moors, E., Munger, J. W., Pilegaard, K., Rannik, Ü., Rebmann, C., Suyker, A., Tenhunen, J., Tu, K., Verma, S., Vesala, T., Wilson, K., and Wofsy, S.: Gap filling strategies for defensible annual sums of net ecosystem exchange, Agric. Forest Meteorol., 107, 43-69, 2001.

Fan, S.-M., Wofsy, S. C., Bakwin, P. S., Jacob, D. J., and Fitzjarrald, D. R.: Atmosphere-biosphere exchange of $\mathrm{CO}_{2}$ and $\mathrm{O}_{3}$ in the central Amazon forest, J. Geophys. Res.-Atmos., 95, 1685116864, 1990.

Finkelstein, P. L. and Sims, P. F.: Sampling error in eddy correlation flux measurements, J. Geophys. Res., 106, 3503-3509, https://doi.org/10.1029/2000JD900731, 2001.

Fraser, L. and Keddy, P.: The World's Largest Wetlands: Ecology and Conservation, Cambridge University Press, Cambridge, 2005.

Fratini, G., Ibrom, A., Arriga, N., Burba, G., and Papale, D.: Relative humidity effects on water vapour fluxes measured with closed-path eddy-covariance systems with short sampling lines, Agric. Forest Meteorol., 165, 53-63, 2012.

Fritz, C.: Limits of Sphagnum bog growth in the New World: biogeochemistry and ecohydrology of peatlands in South America and New Zealand, PhD thesis, Radboud University Nijmegen, 
available at: http://hdl.handle.net/2066/92745 (last access: 2 August 2019), 2012.

Fritz, C., Pancotto, V. A., Elzenga, J. T. M., Visser, E. J. W., Grootjans, A. P., Pol, A., Iturraspe, R., Roelofs, J. G. M., and Smolders, A. J. P.: Zero methane emission bogs: extreme rhizosphere oxygenation by cushion plants in Patagonia, New Phytologist, 190, 398-408, 2011.

Gash, J. H. C. and Culf, A. D.: Applying a linear detrend to eddy correlation data in realtime, Bound.-Layer Meteorol., 79, 301306, 1996

Glaser, P., Chanton, J., Morin, P., Rosenberry, D., Siegel, D., Ruud, O., Chasar, L., and Reeve, A. S.: Surface deformations as indicators of deep ebullition fluxes in a large northern peatland, Global Biogeochem. Cy., 18, GB1003, https://doi.org/10.1029/2003GB002069, 2004.

Godoy, R., Paulino, L., Oyarzún, C., and Boeckx, P.: Atmospheric $\mathrm{N}$ deposition in central and southern Chile. An overview, Gayana Botánica, 60, 47-53, 2003.

Goodrich, J., Campbell, D., Clearwater, M., Rutledge, S., and Schipper, L.: High vapor pressure deficit constrains GPP and the light response of NEE at a Southern Hemisphere bog, Agric. Forest Meteorol., 203, 54-63, 2015a.

Goodrich, J., Campbell, D., Roulet, N., Clearwater, M., and Schipper, L.: Overriding control of methane flux temporal variability by water table dynamics in a Southern Hemisphere, raised bog, J. Geophys. Res.-Biogeo., 120, 819-831, 2015 b.

Govaerts, R.: World Checklist of Asteliaceae, Facilitated by the Royal Botanic Gardens, Kew, available at: http://wcsp.science. kew.org, last access: 28 February 2019.

Grootjans, A., Iturraspe, R., Lanting, A., Fritz, C., and Joosten, H.: Ecohydrological features of some contrasting mires in Tierra del Fuego, Argentina, Mires Peat, 6, 1-15, 2010.

Grootjans, A., Iturraspe, R., Fritz, C., Moen, A., and Joosten, H.: Mires and mire types of Peninsula Mitre, Tierra del Fuego, Argentina, Mires Peat, 14, 1-20, 2014.

Harris, L. I., Moore, T. R., Roulet, N. T., and Pinsonneault, A. J.: Lichens: A limit to peat growth?, J. Ecol., 106, 2301-2319, https://doi.org/10.1111/1365-2745.12975, 2018

Heusser, C.: Palaeoecology of a Donatia-Astelia cushion bog, Magellanic Moorland-Subantarctic evergreen forest transition, southern Tierra del Fuego, Argentina, Revi. Palaeobot. Palyno., 89, 429-440, 1995.

Holl, D.: Carbon dioxide and methane balances of pristine and degradd temperate peatlands - Empirircal modeling of eddy covariance trace gas fluxes measured over heterogeneous terrain, Hamburger Bodenkundliche Arbeiten, 82, 1-139, 2017.

Holl, D., Wille, C., Sachs, T., Schreiber, P., Runkle, B. R. K., Beckebanze, L., Langer, M., Boike, J., Pfeiffer, E.-M., Fedorova, I., Bolshianov, D. Y., Grigoriev, M. N., and Kutzbach, L.: A long-term (2002 to 2017) record of closed-path and open-path eddy covariance $\mathrm{CO} 2$ net ecosystem exchange fluxes from the Siberian Arctic, Earth Syst. Sci. Data, 11, 221-240, https://doi.org/10.5194/essd-11-221-2019, 2019.

Hollinger, D. Y., Goltz, S. M., Davidson, E. a., Lee, J. T., Tu, K., and Valentine, H. T.: Seasonal patterns and environmental control of carbon dioxide and water vapour exchange in an ecotonal boreal forest, Global Change Biol., 5, 891-902, 1999.
Horst, T. W. and Lenschow, D. H.: Attenuation of scalar fluxes measured with spatially-displaced sensors, Bound.-Lay. Meteorol., 130, 275-300, 2009.

Ibrom, A., Dellwik, E., Flyvbjerg, H., Jensen, N. O., and Pilegaard, K.: Strong low-pass filtering effects on water vapour flux measurements with closed-path eddy correlation systems, Agric. Forest Meteorol., 147, 140-156, 2007a.

Ibrom, A., Dellwik, E., Larsen, S. E., and Pilegaard, K.: On the use of the Webb-Pearman-Leuning theory for closed path eddy correlation measurements, Tellus B, 59, 937-946, 2007b.

Iturraspe, R.: Las turberas de Tierra del Fuego y el Cambio Climático global, Fundación Humedales/Wetlands International, Buenos Aires, 2010.

Iturraspe, R.: Spatial analysis and description of eastern peatlands of Tierra del Fuego, Argentina, in: Mires from Pole to Pole, edited by: Lindholm, T., Heikkilä, R., and Ympäristökeskus, S., pp. 385-389, Finnish Environment Inst., Helsinki, 2012.

Kaimal, J. and Finnigan, J.: Atmospheric Boundary Layer Flows: Their structure and measurements, Oxford University Press, Oxford, 1994.

Kaimal, J. C., Wyngaard, J. C., Izumi, Y., and Coté, O. R.: Spectral characteristics of surface-layer turbulence, Q. J. Roy. Meteor. Soc., 98, 563-589, 1972.

Kleinebecker, T., Hölzel, N., and Vogel, A.: Gradients of continentality and moisture in South Patagonian ombrotrophic peatland vegetation, Folia Geobotanica, 42, 363-382, 2007.

Kleinebecker, T., Hölzel, N., and Vogel, A.: South Patagonian ombrotrophic bog vegetation reflects biogeochemical gradients at the landscape level, J. Veg. Sci., 19, 151-160, 2008.

Koehler, A.-K., Sottocornola, M., and Kiely, G.: How strong is the current carbon sequestration of an Atlantic blanket bog?, Global Change Biol., 17, 309-319, 2011.

Kutzbach, L.: AmeriFlux AR-TF1 Rio Moat bog, https://doi.org/10.17190/AMF/1543389, 2019a.

Kutzbach, L.: AmeriFlux AR-TF2 Rio Pipo bog, https://doi.org/10.17190/AMF/1543388, 2019b.

Laine, A., Sottocornola, M., Kiely, G., Byrne, K. A., Wilson, D., and Tuittila, E.-S.: Estimating net ecosystem exchange in a patterned ecosystem: Example from blanket bog, Agric. Forest Meteorol., 138, 231-243, 2006.

Lehmann, J. R. K., Münchberger, W., Knoth, C., Blodau, C., Nieberding, F., Prinz, T., Pancotto, V. A., and Kleinebecker, T.: High-Resolution Classification of South Patagonian Peat Bog Microforms Reveals Potential Gaps in Up-Scaled CH4 Fluxes by use of Unmanned Aerial System (UAS) and CIR Imagery, Remote Sensing, 8, 173, https://doi.org/10.3390/rs8030173, 2016.

Loisel, J. and Yu, Z.: Holocene peatland carbon dynamics in Patagonia, Quaternary Sci. Rev., 69, 125-141, 2013.

Loisel, J., Yu, Z., Beilman, D. W., Camill, P., Alm, J., Amesbury, M. J., Anderson, D., Andersson, S., Bochicchio, C., Barber, K., Belyea, L. R., Bunbury, J., Chambers, F. M., Charman, D. J., De Vleeschouwer, F., Fiałkiewicz-Kozieł, B., Finkelstein, S. A., Gałka, M., Garneau, M., Hammarlund, D., Hinchcliffe, W., Holmquist, J., Hughes, P., Jones, M. C., Klein, E. S., Kokfelt, U., Korhola, A., Kuhry, P., Lamarre, A., Lamentowicz, M., Large, D., Lavoie, M., MacDonald, G., Magnan, G., Mäkilä, M., Mallon, G., Mathijssen, P., Mauquoy, D., McCarroll, J., Moore, T. R., Nichols, J., O’Reilly, B., Oksanen, P., Packalen, M., Peteet, D., Richard, P. J. H., Robinson S., Ronkainen, T., Rundgren, M., 
Sannel, A. B. K., Tarnocai, C., Thom, T., Tuittila, E.-S., Turetsky, M., Väliranta, M., van der Linden, M., van Geel, B., van Bellen, S., Vitt, D., Zhao, Y., and Zhou, W.: A database and synthesis of northern peatland soil properties and Holocene carbon and nitrogen accumulation, The Holocene, 24, 1028-1042, 2014.

Lund, M., Bjerke, J. W., Drake, B. G., Engelsen, O., Hansen, G. H., Parmentier, F. J. W., Powell, T. L., Silvennoinen, H., Sottocornola, M., Tømmervik, H., Weldon, S., and Rasse, D. P.: Low impact of dry conditions on the $\mathrm{CO}_{2}$ exchange of a Northern-Norwegian blanket bog, Environ. Res. Lett., 10, 025004, https://doi.org/10.1088/1748-9326/10/2/025004, 2015.

Mahecha, M. D., Reichstein, M., Carvalhais, N., Lasslop, G., Lange, H., Seneviratne, S. I., Vargas, R., Ammann, C., Arain, M. A., Cescatti, A., Janssens, I. A., Migliavacca, M., Montagnani, L., and Richardson, A. D.: Global convergence in the temperature sensitivity of respiration at ecosystem level, Science, 329, 838-840, 2010.

Mark, A. F., Johnson, P. N., Dickinson, K. J. M., and McGlone, M. S.: Southern hemisphere patterned mires, with emphasis on southern New Zealand, J. Roy. Soc. New Zealand, 25, 23-54, 1995.

Markgraf, V. and Huber, U. M.: Late and postglacial vegetation and fire history in Southern Patagonia and Tierra del Fuego, Palaeogeogr. Palaeocl., 297, 351-366, 2010.

Mauder, M. and Foken, T.: Documentation and instruction manual of the eddy covariance software package TK2, Univ, Arbeitsergebnisse, Universität Bayreuth, Abt. Mikrometeorologie, 26, 45 pp., 2004.

Mauquoy, D. and Bennett, K. D.: Peatlands in Tierra del Fuego, in: The biology of peatlands, edited by: Rydin, H. and Jeglum, J. K., Oxford University Press, Oxford, 2006.

Moen, A., Couwenberg, J., and Joosten, H.: Comments on the regional variation and mires in Tierra del Fuego-a comparison with Fennoscandia, International Mire Conservation Group Newsletter, 4, 11-13, 2005.

Moncrieff, J., Valentini, R., Greco, S., Guenther, S., and Ciccioli, P.: Trace gas exchange over terrestrial ecosystems: methods and perspectives in micrometeorology, J. Exp. Bot., 48, 1133-1142, 1997.

Moncrieff, J., Clement, R., Finnigan, J., and Meyers, T.: Averaging, detrending, and filtering of eddy covariance time series, in: Handbook of micrometeorology, edited by: Lee, X., Massman, W., and Law, B., pp. 7-31, Springer Netherlands, Dordrecht, 2004.

Moore, D.: Flora of Tierra Del Fuego, A. Nelson Ltd., Shrewsbury, 1983.

Moore, T. R., Bubier, J. L., Frolking, S. E., Lafleur, P. M., and Roulet, N. T.: Plant biomass and production and $\mathrm{CO}_{2}$ exchange in an ombrotrophic bog, J. Ecol., 90, 25-36, 2002.

Münchberger, W., Knorr, K.-H., Blodau, C., Pancotto, V. A., and Kleinebecker, T.: Zero to moderate methane emissions in a densely rooted, pristine Patagonian bog - biogeochemical controls as revealed from isotopic evidence, Biogeosciences, 16, 541-559, https://doi.org/10.5194/bg-16-541-2019, 2019.

Nakai, T., Van der Molen, M., Gash, J., and Kodama, Y.: Correction of sonic anemometer angle of attack errors, Agric. Forest Meteorol., 136, 19-30, 2006.

Pisano, E.: Fitogeografía de Fuego-Patagonia chilena. I.Comunidades vegetales entre las latitudes 52 y $56^{\circ} \mathrm{S}$, in:
Anales del Instituto de la Patagonia, Instituto Patagonia, Punta Arenas, 1977.

Pisano, E.: Magellanic Tundra complex, in: Ecosystems of the World, 4B (Regional Studies): Mires, swamp, bog, fen and moor., pp. 295-329, Elsevier, Amsterdam, 1983.

Ponce, J. F. and Fernández, M.: Climatic and environmental history of Isla de los Estados, Argentina, Springer, New York, 2014.

Ponce, J. F., Borromei, A. M., Menounos, B., and Rabassa, J.: Late-Holocene and Little Ice Age palaeoenvironmental change inferred from pollen analysis, Isla de los Estados, Argentina, Quaternary Int., 442, 26-34, https://doi.org/10.1016/j.quaint.2016.04.016, 2016.

Rabassa, J., Coronato, A., and Heusser, C.: Peat-bog accumulation rate in the Andes of Tierra del Fuego and Patagonia (Argentina and Chile) during the last 43.000 years, Pirineos, 133, 113-122, 1989.

Rabassa, J., Coronato, A., and Roig, C.: The peat bogs of Tierra del Fuego, Argentina, in: Global peat resources, edited by: Lappalainen, E., pp. 261-266, International Peat Society, Jyväskylä, 1996.

Rabassa, J., Coronato, A., Bujalesky, G., Salemme, M., Roig, C., Meglioli, A., Heusser, C., Gordillo, S., Roig, F., Borromei, A., and Quattrocchio, M.: Quaternary of Tierra del Fuego, Southernmost South America: an updated review, Quaternary Int., 68-71, 217-240, 2000.

Rabassa, J., Coronato, A., Heusser, C., Juñent, F. R., Borromei, A., Roig, C., and Quattrocchio, M.: Chapter 6 The peatlands of Argentine Tierra del Fuego as a source for paleoclimatic and paleoenvironmental information, in: PeatlandsEvolution and Records of Environmental and Climate Changes, edited by: Martini, I. P., Martínez Cortizas, A., and Chesworth, W., vol. 9 of Developments in Earth Surface Processes, pp. 129-144, Elsevier, Amsterdam, 2006.

Roig, C., Roig, F., Collado, L., Coronato, A., Martínez Carretero, E., and Barrios, V.: Inventario de los turbales de la zona centro de la provincia de Tierra del Fuego. Informe final, CFISubsecretaría de Recursos Naturales, provincia de Tierra del Fuego, Antártida e Islas del Atlántico Sur, Ushuaia, 2001.

Roivainen, H.: Studien über die Moore Feuerlands, Annales Botanici Societatis Zooligicae Botanicae Fennicae "Vanamo", Societas Zoologica Botanica Fennica Vanamo, Helsink, 28, 1954.

Roulet, N. T., Lafleur, P. M., Richard, P. J., Moore, T. R., Humphreys, E. R., and Bubier, J.: Contemporary carbon balance and late Holocene carbon accumulation in a northern peatland, Global Change Biol., 13, 397-411, 2007.

Runkle, B. R. K., Sachs, T., Wille, C., Pfeiffer, E.-M., and Kutzbach, L.: Bulk partitioning the growing season net ecosystem exchange of $\mathrm{CO}_{2}$ in Siberian tundra reveals the seasonality of its carbon sequestration strength, Biogeosciences, 10, 1337-1349, https://doi.org/10.5194/bg-10-1337-2013, 2013.

Sottocornola, M. and Kiely, G.: An Atlantic blanket bog is a modest $\mathrm{CO}_{2}$ sink, Geophys. Res. Lett., 32, L23804, https://doi.org/10.1029/2005GL024731, 2005.

Sottocornola, M. and Kiely, G.: Hydro-meteorological controls on the $\mathrm{CO}_{2}$ exchange variation in an Irish blanket bog, Agric. Forest Meteorol., 150, 287-297, 2010.

Sottocornola, M., Laine, A., Kiely, G., Byrne, K. A., and Tuittila, E.-S.: Vegetation and environmental variation in an Atlantic 
blanket bog in South-western Ireland, Plant Ecol., 203, 69-81, 2009.

Thornley, J.: Dynamic model of leaf photosynthesis with acclimation to light and nitrogen, Ann. Bot., 81, 421-430, 1998.

Tuhkanen, S.: Tierra Del Fuego as a Target for Biogeographical Research in the Past and Present, Anales del Instituto de la Patagonia: Serie ciencias naturales, Instituto de la Patagonia, Punta Arenas, 1990.

Tuhkanen, S.: The climate of Tierra del Fuego from a vegetation geographical point of view and its ecoclimatic counterparts elsewhere, Finnish Botanical Publishing Board, Helsinki, 1992.

Ulloa Ulloa, C., Acevedo-Rodríguez, P., Beck, S., Belgrano, M. J., Bernal, R., Berry, P. E., Brako, L., Celis, M., Davidse, G., Forzza, R. C., Gradstein, S. R., Hokche, O., León, B., León-Yánez, S., Magill, R. E., Neill, D. A., Nee, M., Raven, P. H., Stimmel, H., Strong, M. T., Villaseñor, J. L., Zarucchi, J. L., Zuloaga, F. O., and Jørgensen, P. M.: An integrated assessment of the vascular plant species of the Americas, Science, 358, 1614-1617, https://doi.org/10.1126/science.aao0398, 2017.

Vanneste, H., De Vleeschouwer, F., Martínez-Cortizas, A., Von Scheffer, C., Piotrowska, N., Coronato, A., and Le Roux, G.: Late-glacial elevated dust deposition linked to westerly wind shifts in southern South America, Sci. Rep-UK, 5, 11670, https://doi.org/10.1038/srep11670, 2015.
Van 't Hoff, J. H.: Lectures on theoretical and physical chemistry, Part 1: Chemical Dynamics, E. Arnold, London, 1898.

Vickers, D. and Mahrt, L.: Quality control and flux sampling problems for tower and aircraft data, J. Atmos. Ocean. Tech., 14, 512 526, 1997.

von Post, L.: Sveriges Geologiska Undersöknings torvinventering och några av dess hittills vunna resultat, Svenska Mosskulturforeningens Tidskrift, pp. 1-27, 1922.

Weischet, W.: Climatic constraints for the development of the far south of Latin America, GeoJournal, 11, 79-87, 1985.

Yu, Z., Loisel, J., Brosseau, D. P., Beilman, D. W., and Hunt, S. J.: Global peatland dynamics since the Last Glacial Maximum, Geophys. Res. Lett., 37, 113402, https://doi.org/10.1029/2010GL043584, 2010.

Zheng, Y., Zhao, Z., Zhou, J.-J., and Zhou, H.: Evaluations of different leaf and canopy photosynthesis models: a case study with black locust (Robinia pseudoacacia) plantations on a loess plateau, Pakistan Journal of Botany, 44, 531-539, 2012. 